\title{
Studies into the Synthesis of Derivatives of 4-Amino-2,3-Dihydroisothiazole 1,1-Dioxides and 4-Amino-1,2-Oxathiole 2,2-Dioxides: The Search for Linked $\pi$-System Containing Analogues as Potential Inhibitors of HIV-1 Reverse Transcriptase
}

\author{
Simon T. Ingate, 1 José L. Marco, ${ }^{1, *}$ Myriam Witvrouw, ${ }^{2}$ Cristophe Pannecouque, $^{2}$ and Erik \\ De Clercq $^{2}$ \\ 'Instituto de Química Orgánica General (CSIC), C/ Juan de la Cierva 3, 28006-Madrid, Spain. \\ ${ }^{2}$ Rega Institute for Medical Research, Katholieke Universiteit Leuven, B-3000 Leuven, Belgium.
}

\begin{abstract}
The synthesis, and anti HIV-1 activity, of new derivatives of 4-amino-1.2oxathiole 2,2-dioxide (3,5,6 and 9) and 4-amino-2,3-dihydroisothiazole 1,1-dioxide (14). a new heterocyclic ring system, is described. 1997 Elsevier Science Ltd.
\end{abstract}

\section{INTRODUCTION}

The search for products as drugs for the treatment of AIDS is a very active field of research. There now exist inhibitors targeted at various stages of the life cycle of the human immunodeficiency virus (HIV). although as yet only reverse transcriptase (RT) and protease inhibitors are currently used in the treatment of this disease.

One of the most competitive areas of investigation has been the search for of RT inhibitors. due predominantly to the early successes achieved with nucleoside derivatives such as AZT and DDC. ${ }^{2.3}$ Since the early nineties there have appeared a variety of non-nucleoside reverse transcriptase inhibitors (NNRTIs) that function by a different mechanism to the nucleoside inhibitors, binding at an allosteric pocket close to the polymerase active site of the RT of HIV type $1 .{ }^{2,4-10}$ Nucleobase derivatives have been quite thoroughly investigated as HIV-1 RT inhibitors; these include the HEPT and DABO families of compounds, some of which are very active. ${ }^{9,10}$ These compounds (see Chart 1) are only active against HIV-1 RT; they do not exhibit activity against other retroviral (including HIV-2) reverse transcriptases, and, unlike the nucleoside derivatives. they do not affect human polymerases or require normal cellular kinases, which consequently allows the most potent of these compounds to act as highly specific and non-toxic AIDS drugs. 
Chart 1. Non-nucleoside reverse transcriptase inhibitors<smiles>O=[SH]1(c2ccccc2)N=C(S)Nc2ccccc21</smiles>

NSC287474<smiles>N#CCN1C(=O)N(Cc2ccccc2)S(=O)(=O)c2cscc21</smiles>

QM96521

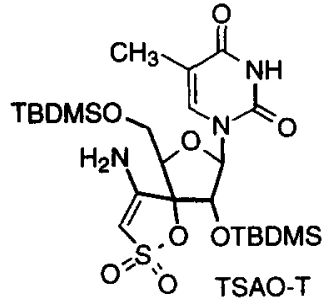<smiles>CC(=O)c1ccc(C)cc1NC(C(N)=O)c1c(Cl)cccc1Cl</smiles>
R89439<smiles>S=C(NCCc1ccccn1)Nc1ccc(Br)cn1</smiles><smiles>[R]c1c(Sc2ccccc2)n(COCC)c(=O)[nH]c1=O</smiles>

HEPT<smiles>Cc1cccc(Cc2cc(=O)[nH]c(OC3CCCC3)n2)c1</smiles>

The majority of these compounds, although of diverse chemical structure contain two $\pi$-electron systems separated by a linker that varies in length from none (ie. NSC287474) ${ }^{4}$ to three (ie. Troviride) ${ }^{8}$ linker atoms (Chart 1). The active conformation, that was found by X-ray crystallography of drug-enzyme complexes, for these compounds ${ }^{11}$ has been called the "butterfly" conformation, ${ }^{12}$ due to its resemblance to the half-open wings of a resting butterfly. The "hinge" angle formed between the planes of the two $\pi$ systems lies normally within the range $100^{\circ}<\theta<115^{\circ}$ (Figure 1).

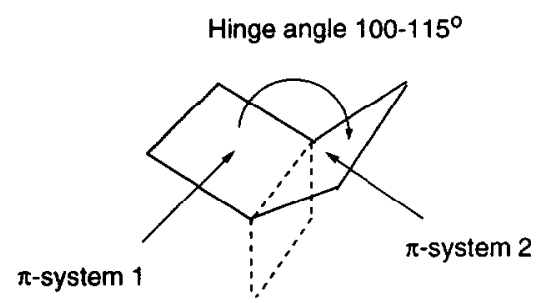

Figure 1. The "butterfly" conformation

Although in TSAO-T ${ }^{6}$ the two $\pi$-electron systems, represented by the spiro-sulfone ring and the pyrimidine base, probably adopt a similar conformation, biological results suggest that the 5'-O TBDMS protecting group is essential for effective binding of this compound to RT. Removal of the 5'-O protecting group in TSAO-T, its substitution or changes in the configuration of the neighbouring C-4' all result in either less active or completely inactive compounds. ${ }^{6,13,14}$ In addition, TBDMS group in TSAO-T is acid-labile. and metaholism studies have shown that both TBDMS moieties are lost rapidly in vivo. ${ }^{15}$ Other spiro heterocylecontaining TSAO derivatives have been prepared, all of them being inactive. ${ }^{16}$ The active TSAO-T molecule and analogues are only available in poor overall yield $(17 \%)$, following a long and time-consuming synthetic scheme (8 steps) from 5-O-benzoyl-1,2- $O$-isopropylidene- $\alpha$-D-xylofuranose (this compound has to be prepared in three additional steps from D-xylose). 6,13 Only one simple analogue, a 4-amino-1,2-oxathiole-2,2-dioxide derivative 
of adamantane, has been prepared as a potential antiviral agent (before the necessity of linked $\pi$-systems became obvious); this compound unfortunately lacked activity. ${ }^{17}$

We decided to study new compounds of a simple structure based upon the 4-amino-1,2-oxathiole 2.2dioxide ring system. Figure 2 illustrates our strategy, we selected either phenyl or substituted phenyl rings as the second $\pi$-electron containing substituent. The position and the length of the linker could then be varied at will: for simplicity we decided to maintain the $\mathrm{SO}_{2}$ group although we thought it would be interesting to study the substitution of the ring oxygen by nitrogen to give the previously unknown 4-amino-2,3-dihydroisothiazole 1.1dioxide ring system. ${ }^{18}$

The first compounds that we needed to prepare, however, were the simple single ring containing compounds (Figure 3 ) in order to test the feasibility of our planned synthetic routes. $\mathrm{N}$-benzyl derivatives containing a second $\pi$-system, and compounds substituted at the carbon adjacent to the $\mathrm{SO}_{2}$ group could be readily prepared from these initial target compounds (Figure 3).

Figure 2. Synthetic strategy

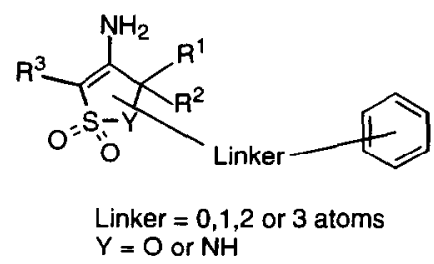

Figure 3. Initial target compounds.<smiles>[R]C1=C(N)C(C)(C)[Te]2(=O)O[Si]12</smiles>

$\mathrm{R}=\mathrm{H}, \mathrm{CH}_{3}$ or $\mathrm{Ph}$

$\mathrm{Y}=\mathrm{O}$ or $\mathrm{NR}$

\section{RESULTS AND DISCUSSION}

The 1,2-oxathiole 2,2-dioxide systems described here have been constructed from ketones in three steps (Scheme 1) the first step being cyanohydrin formation. followed by synthesis of the alkyl sulfonate derivatives and ultimately ring closure with an appropriate base. We first examined the $\mathrm{C}-3$ substituted derivatives since their synthesis could be carried out by changing the sulfonyl chloride used. These sulfonyl chlorides should contain a potential methylene group and we chose the commercially available methane, ethane and benzyl sulfonyl chlorides as representative examples in order to examine the cyclization reaction. The mechanism proposed for this cyclization ${ }^{19}$ requires the abstraction of a proton from the methyl group of the methane sulfonate in order to generate a carbanion that attacks the cyano carbon. Proton migration results in the formation of the pentacycle bearing the amino group. We decided to limit our preliminary studies to ketones since we believed that the proton on the trisubstituted carbon of the cyanomesylate derived from an aldehyde could be more acidic than the mesyl protons which could possibly lead to unwanted side reactions.

Acetone cyanohydrin in dichloromethane was thus reacted with an excess of the sulfonyl chloride with triethylamine as base to give, after chromatography, the alkyl sulfonates ( $2 \mathrm{a}$ to $2 \mathrm{c}$ ) in good yields $(60-74 \%)$. The cyclization of the cyanomesylate in the TSAO derivatives is usually carried out with either $\mathrm{Cs}_{2} \mathrm{CO}_{3}$ in acetonitrile and on occasions where unwanted rearrangements have been observed DBU has been used with success. ${ }^{6,13,14,16 a}$ We found that a catalytic amount of DBU was sufficient to cyclize compounds $2 \mathrm{a}$ and $2 \mathrm{c}$. the latter extremely rapidly due to its highly activated methylene group. Compound $2 \mathbf{b}$ failed to ring-close under 
these conditions due to the deactivating effect of the neighbouring methyl functionality. The 3-methyl-4-amino1,2-oxathiole 2,2-dioxide 3b was readily synthesized, however, when $\mathrm{NaH}$ was used as a base. This method of

Scheme 1. Synthesis of derivatives of 4-amino-1,2-oxathiole 2,2-dioxides.

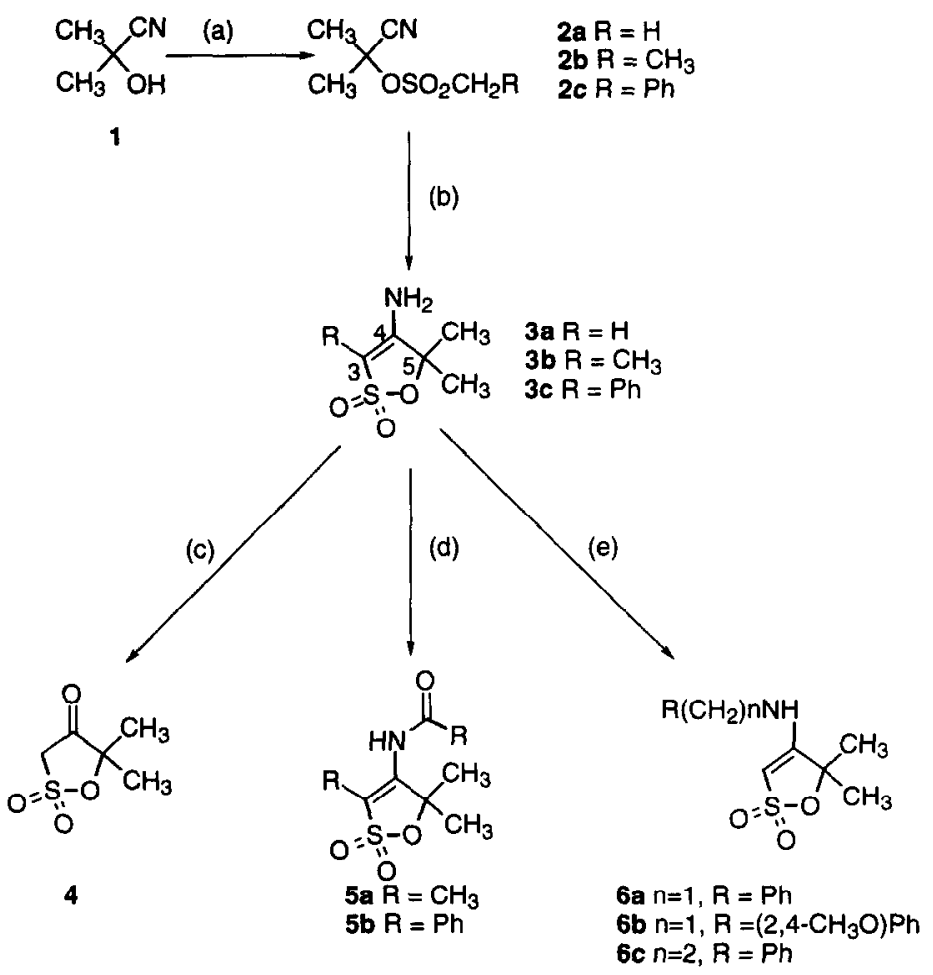

Reagents and conditions: (a) $\mathrm{RCH}_{2} \mathrm{SO}_{2} \mathrm{Cl}, \mathrm{Et}_{3} \mathrm{~N}, \mathrm{CH}_{2} \mathrm{Cl}_{2}, 0^{\circ} \mathrm{C}$ to rt; (b) $\mathrm{NaH}$ or $\mathrm{DBU}, \mathrm{CH}_{3} \mathrm{CN}$, $\mathrm{rt}$; (c) $\mathrm{HCl}$. EtOH, rt; (d) $\mathrm{PhCOCl}$ or $\left(\mathrm{CH}_{3} \mathrm{CO}\right)_{2} \mathrm{O}, \mathrm{DMAP}, \mathrm{CH}_{3} \mathrm{CN}$, rt; (e) $\mathrm{Ph}\left(\mathrm{CH}_{2}\right) \mathrm{nNH}_{2}$, EtOH, reflux.

cyclization was found to be more convenient since in general the reaction is quicker, giving the pure product after aqueous work-up and recrystallisation whilst the DBU catalyzed reaction normally requires purification by column chromatography.

The chemical reactivity of this heterocyclic system has been studied only slightly and we thought some work in this area should be concentrated on the reactivity of the amino group. Acid hydrolysis ( $\mathrm{HCl}$ in $\mathrm{EtOH})$ in related compounds ${ }^{17}$ converted the spiro 4-amino-1,2-oxathiole 2,2-dioxide moiety to a spiro 4-oxo-3.5dihydro-1,2-oxathiole. In our system 3a gave the known compound $4{ }^{20}$ under the same reaction conditions. The amino group attached to the double bond is particularly interesting, we wished to determine whether it would behave as a normal amino group since $a b$ initio calculations of $3 \mathrm{a}^{21}$ suggest that this nitrogen is mainly of $\mathrm{sp}^{2}$ character but with slight non-planarity. Thus, we expected this nitrogen to behave as an enamino or amide nitrogen. The $\mathrm{N}$-acyl derivatives $5 \mathrm{a}$ and $5 \mathrm{~b}$ were prepared by reacting $3 \mathrm{a}$ in $\mathrm{CH}_{3} \mathrm{CN}$ with acetic anhydride and benzoyl chloride respectively in the presence of $4-N, N$-dimethylaminopyridine (DMAP), albeit in rather low 
yields (these reactions have not been optimized). Alkylation of the amino group was attempted under various conditions, but complex mixtures were always obtained. Since these molecules contain an enamine of ammonia we thought that it may be possible to substitute the amino group by other amines. The $N$-benzyl and $\mathrm{N}$ phenylethyl derivatives (6a-c) were obtained via transamination reactions between 3a and amines. The reactions were carried out by reacting the heterocycle with excess amine in refluxing ethanol for several days. $22 \mathrm{We}$ studied only aromatic ring containing amines since we wished to produce potential HIV-1 RT inhibitor containing linked $\pi$ systems.

Scheme 2. Mechanism of the formation of the $N$-alkyl derivatives of $\mathbf{3 a}$.

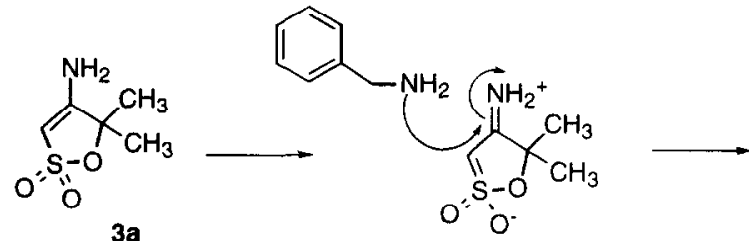

3a<smiles>CC1(C)OS(=O)(=O)CC1(N)N[NH+](Cc1ccccc1)Cc1ccccc1</smiles>

6a'
$3 a$<smiles>CC1(C)OS(=O)(=O)C=C1NCc1ccccc1</smiles>

6a

We believe that the reaction proceeds via the attack by the incoming amine on an imine intermediate (Scheme 2). This type of transformation has been described for the conversion of amino-pteridines of to their $\mathrm{N}$ alkylamine derivatives. ${ }^{22}$ In our systems the imine intermediate may be formed by adoption of the zwitterionic species $3 \mathbf{a}^{\prime}$. The amine attacks this species to give $6 \mathbf{a}^{\prime}$ which upon release of ammonia gives $6 \mathbf{a}$. We cannol fully rule out the possibility of a ketone intermediate (i.e. compound 4) atthough this species was not observed during the reaction as monitored by TLC. We are at the moment studying the use of secondary amines as protecting groups which may allow us to synthesise $\mathrm{C}-3$ derivatives not readily available via ring closure of sulfonyl chlorides. Reaction of such derivatives with saturated ammonia solution should regenerate the C-4 amino group whilst acid hydrolysis would give us 3-substituted-4-oxy- $\gamma$-sulfones. ${ }^{20}$

The use of ketones other than acetone allows the synthesis of compounds with different functionality it C-5 (Scheme 3). We decided to initially limit our investigations to methyl ketones since we had in mind the idea of attempting enzyme catalyzed asymmetric cyanohydrin formation at a later stage. Should these compound: exhibit interesting activity we could later produce them as single, enantiomerically pure isomers. It is well known that some methyl ketones are substrates for the $(R)$-oxynitrilase enzyme extracted from almonds..; although aldehydes are preferred. Another possibility would be asymmetric chemical synthesis of the cyanohydrins which would allow us to use more diverse ketone starting materials. ${ }^{24}$

Continuing with the theme of dual linked $\pi$ systems, we chose benzylmethyl ketone and O-benzoyl acetol ${ }^{25}$ each containing an aromatic ring in order to provide the second $\pi$ system with one or two atoms in the linker part, respectively (since the COPh of the benzoyl group constitutes a single $\pi$ unit). The synthesis of the 
cyanohydrin derivatives was straightforward involving rapidly stirring a solution of the ketone dissolved in diethyl ether with an aqueous solution containing sodium cyanide and sodium hydrogen carbonate until the ketone disappeared. Although other, higher yielding procedures ie. via TMS protected cyanohydrins are possible, ${ }^{26}$ this more direct method was chosen as it has the advantage that it is easier to scale-up and because

Scheme 3. Synthesis of C-5 substituted derivatives of 4-amino-1,2-oxathiole 2,2-dioxides.

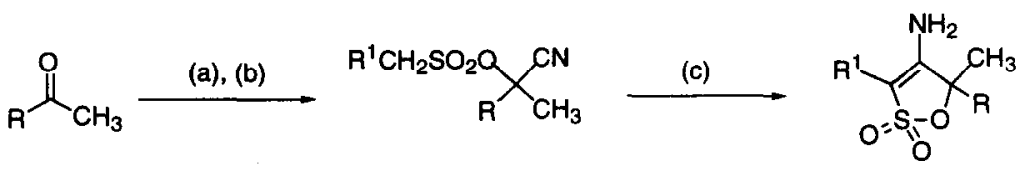

7a $\mathrm{R}=\mathrm{CH}_{2} \mathrm{Ph}$
$7 \mathbf{b ~ R}=\mathrm{CH}_{2} \mathrm{OCOPh}$

$$
\begin{aligned}
& \text { 8a } \mathrm{R}=\mathrm{CH}_{2} \mathrm{Ph}, \mathrm{R}^{1}=\mathrm{H} \\
& \text { 8b } \mathrm{R}=\mathrm{CH}_{2} \mathrm{Ph}, \mathrm{R}^{1}=\mathrm{CH}_{3} \\
& \text { 8c } \mathrm{R}=\mathrm{CH}_{2} \mathrm{Ph}, \mathrm{R}^{1}=\mathrm{Ph} \\
& \text { 8d } \mathrm{R}=\mathrm{CH}_{2} \mathrm{OCOPh}, \mathrm{R}^{1}=\mathrm{H}
\end{aligned}
$$

$$
\begin{aligned}
& \text { 9a } \mathrm{R}=\mathrm{PhCH}_{2}, \mathrm{Rl}=\mathrm{H} \\
& \text { 9b } \mathrm{R}=\mathrm{PhCH}_{2}, \mathrm{Rl}=\mathrm{CH}_{3} \\
& \text { 9c } \mathrm{R}=\mathrm{PhCH}_{2}, \mathrm{Rl}=\mathrm{Ph} \\
& \text { 9d } \mathrm{R}=\mathrm{CH}_{2} \mathrm{OCOPh}, \mathrm{R}^{\prime}=\mathrm{H}
\end{aligned}
$$

Reagents and conditions: (a) $\mathrm{NaCN}, \mathrm{NaHCO}_{3}, \mathrm{Et}_{2} \mathrm{O} / \mathrm{H}_{2} \mathrm{O}$; (b) $\mathrm{RCH}_{2} \mathrm{SO}_{2} \mathrm{Cl}, \mathrm{Et}_{3} \mathrm{~N}, \mathrm{CH}_{2} \mathrm{Cl}_{2}, 0^{\prime \prime} \mathrm{C}$ to it: (c) $\mathrm{NaH}$ or DBU, $\mathrm{CH}_{3} \mathrm{CN}$, rt.

we envisaged using a similar method for later enzymatic synthesis. The crude cyanohydrins were isolated by extraction and were used directly for the next reaction step since similar products are notoriously unstable. The alkyl sulfonates (8a-d) were prepared by reaction with alkyl sulfonyl chlorides and triethylamine in dichloromethane. Cyclization of these compounds was carried out in $\mathrm{CH}_{3} \mathrm{CN}$ with either DBU or $\mathrm{NaH}$. The intermediates (8a-8d) reacted smoothly to yield the heterocycles $(9 \mathbf{a - 9 d})$ at room temperature. In the case of 9d, DBU was used, since the use of $\mathrm{NaH}$ resulted in the deprotection of the benzoyl group.

The structures of the 4-amino-1,2-oxathiole 2,2-dioxides formed (compounds 3, 5, 6 and 9) was readily determined by ' $\mathrm{H}$ and ${ }^{13} \mathrm{C}$ NMR experiments, the $\mathrm{C}-3$ ( 82.5 to $\left.128.8 \mathrm{ppm}\right)$ depending upon the $\mathrm{C}-3$ and NH substitutions, C-4 (ca. 149.5 to $160.7 \mathrm{ppm}$ ) and C-5 ( 85 to $88 \mathrm{ppm}$ ) signals of these compounds being particularly diagnostic features. In the proton spectra of the derivatives unsubstituted at C-3 a sharp one proton singlet corresponding to $\mathrm{H}-3$ ( 5.30 to $5.60 \mathrm{ppm}$ ), in $\mathrm{N}$-acylated compounds this signal moves to about $7.2 \mathrm{ppm}$. and a two proton broad singlet due to the amino group (5.66 to $7.50 \mathrm{ppm}$ ) are observed. This broad singlet appears in all derivatives. In the $N$-benzyl and $N$-phenylethyl derivatives this singlet becomes a triplet confirming the position of the alkyl substituent. All new compounds showed excellent analytical data, in good agreement with these structures.

The next modification we tried was the substitution of the ring oxygen atom for nitrogen. This was achieved by carrying out the Strecker synthesis of cyanoamines ${ }^{27}$ instead of cyanohydrin formation. As a first approach we restricted ourselves to acetone which upon further modification would lead to 3,3-dimethyl-2.3dihydroisothiazole 1,1-dioxides. The Strecker reaction between acetone, ammonium chioride, ammonia and sodium cyanide gave the known 2-amino-2-cyanopropane $\mathbf{1 0}^{\mathbf{2 8}}$ in $84 \%$ yield (Scheme 4). This was reacted subsequently with methane, ethane and $\alpha$-toluene sulfonyl chlorides to give the sulfonamides $11 \mathrm{a},{ }^{29} 11 \mathrm{~b}$ and $11 \mathrm{c}$ respectively (Scheme 4). These compounds are stable crystalline solids that can be prepared easily in 
multigram quantities. The cyclization of $11 \mathrm{a}$ to give 12 was attempted under various conditions of base and solvent whithout success. We usually observed the formation of a precipitate when $\mathrm{NaH}$ was used as base. We suspect this is the insoluble sodium salt of 11a.

As we were more interested in producing potential RT inhibitors we decided to synthesize the $N$-benzyl heterocyclic derivatives (14a to 14f) as (a) The benzyl group would protect the nitrogen atom thus preventing the formation of sodium salts during the cyclization process, (b) the removal of the benzyl group would be readily accomplished should we wish to do so and (c) the $N$-benzyl substituted 3,3-dimethyl-2,3dihydroisothiazole 1,1-dioxides would be candidates for screening as RT inhibitors since they contain linked $\pi$ systems. These compounds would resemble slightly the new RT inhibitors, the QM96521 related compounds. that require an $N-2$ benzyl substituent for activity. ${ }^{5}$ Many RT inhibitors bear halogenated phenyls (see Chart H and for this reason we decided to prepare chlorobenzyl derivatives.

Alkylation of the sulfonamides (11a to 11c) was easily performed using $\mathrm{K}_{2} \mathrm{CO}_{3}$ as base in refluxing acetonitrile. In the case of (11c) the benzylation conditions resulted in the formation of not only the required benzyl sulfonamides (13e and 13f) but also the final products (14e and 14f). The derivatives (13a to 13f) were cyclized with $\mathrm{DBU}$ or $\mathrm{NaH}$ to yield the $N$-benzyl substituted 3,3-dimethyl-2,3-dihydroisothiazole 1.1 dioxides 14a to $14 \mathrm{f}$.

Scheme 4. The synthesis of $N$-benzyl derivatives of 4-amino-2.3-dihydroisothiazole 1.1-dioxides

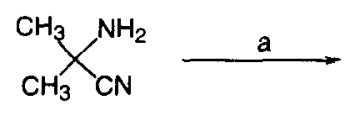

10

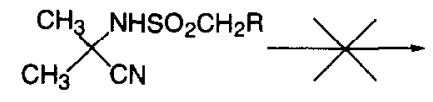

$11 \mathbf{a} \quad \mathrm{R}=\mathrm{H}$

$11 \mathbf{b} \quad \mathrm{R}=\mathrm{CH}_{3}$

11c $\mathrm{R}=\mathrm{Ph}$

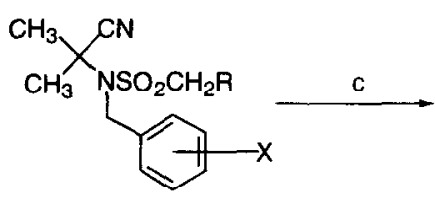

$\begin{array}{ll}\text { 13a } & R=H, X=H \\ \text { 13b } & R=H, X=4-C l \\ \text { 13c } & R=H, X=3-C l \\ \text { 13d } & R=C H H_{3}, X=H \\ 13 e & R=P h, X=H \\ \text { 13f } & R=P h, X=3-C l\end{array}$<smiles>[R]C1=C(N)C(C)(C)NS1(=O)=O</smiles>

12

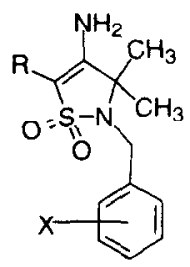

14a $R=H, X=H$

14b $\mathrm{R}=\mathrm{H} . \mathrm{X}=4-\mathrm{Cl}$

14c $\mathrm{R}=\mathrm{H}, \mathrm{X}=3-\mathrm{Cl}$

14d $\mathrm{R}=\mathrm{CH}_{3} . \mathrm{X}=\mathrm{H}$

14e $R=P h, X=H$

$14 f \mathrm{R}=\mathrm{Ph}, \mathrm{X}=3-\mathrm{Cl}$

Reagents and conditions: (a) $\mathrm{RCH}_{2} \mathrm{SO}_{2} \mathrm{Cl}, \mathrm{CH}_{2} \mathrm{Cl}_{2}, \mathrm{Et}_{3} \mathrm{~N} 0^{\circ} \mathrm{C}$ to rt; (b) Benzyl halide, $\mathrm{K}_{2} \mathrm{CO}_{3}$. $\mathrm{CH}_{3} \mathrm{CN}$ : (c) DBU or $\mathrm{NaH}, \mathrm{CH}_{3} \mathrm{CN}$, rt.

We decided not to synthesize the $o$-chlorobenzyl derivatives since we believed that the presence of the chlorine atom close to the two methyl and $\mathrm{SO}_{2}$ groups would lead to the adoption of an unwanted conformation in which the planes of the two $\pi$ electron systems in the final heterocycles would be orthogonal to each other Molecular modelling of the parent compound 14a, see below, confirms this supposition. 
The structure of these new heterocycles has been fully established by correct and satisfactory data obtained by the usual analytical and spectroscopic techniques. The NMR spectra of compounds 14a-14f allow ready structural determination, being very similar to that of related 1,2-oxathiole counterparts.

\section{BIOLOGICAL ACTIVITY}

The compounds were evaluated for their activities against human immunodeficiency virus type 1 (HIV1)(III $\mathrm{B}_{\mathrm{B}}$ ) and HIV-2(ROD) in human T-lymphocyte (MT-4) cells. No anti-HIV activity was observed at concentrations up to $125 \mu \mathrm{g} / \mathrm{ml}$ (data not shown). Most of the compounds showed no toxicity for the host cells at a concentration up to $125 \mu \mathrm{g} / \mathrm{ml}$. One compound, namely $14 \mathrm{~b}$ proved to be toxic to MT-4 cells, at a $50 \%$ cytotoxic concentration $\left(\mathrm{CC}_{50}\right)$ of $75 \mu \mathrm{g} / \mathrm{ml}$.

Chart 2. Stereoviews of the most stable conformations of some representative examples of potential HIV-1 Reverse Transcriptase inhibitors<smiles></smiles>
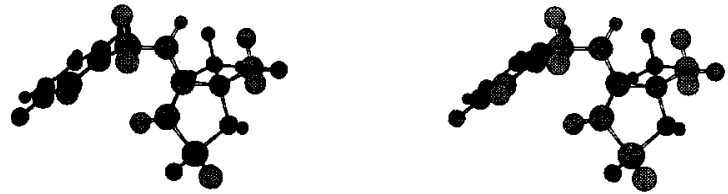<smiles>CC1(C)C(N)=CS(=O)(=O)N1Cc1ccccc1</smiles>
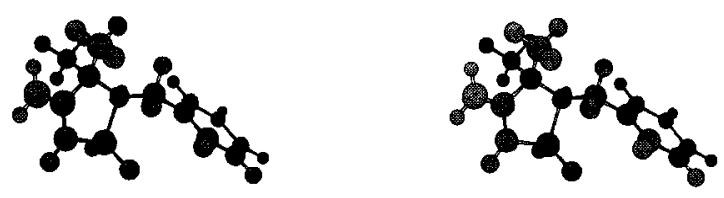<smiles>CC1(Cc2ccccc2)OS(=O)(=O)C=C1N</smiles>
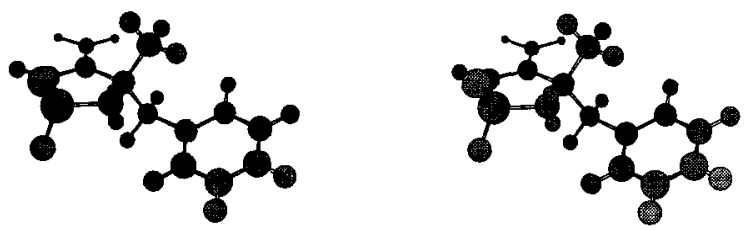<smiles>CC1(COC(=O)c2ccccc2)OS(=O)(=O)C=C1N</smiles>
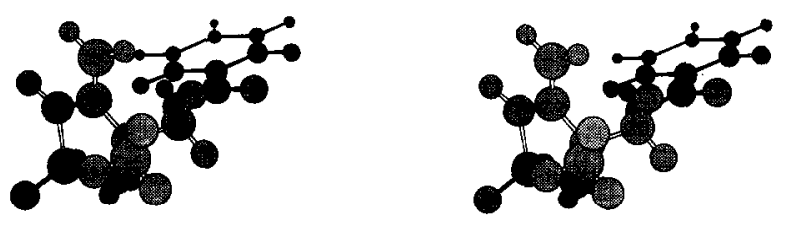


\section{CONCLUSIONS}

Molecular modelling of these compounds ${ }^{30}$ show the relative orientations of the two $\pi$-electron containing components of these compounds (Chart 2). As can readily be appreciated from the stereoviews none of these compounds can adopt a true "butterfly" conformation. The most stable calculated conformation of compound $6 \mathrm{a}$ almost approaches the desired conformation, but interactions between the benzyl substituent and one of the C-5 methyl groups results in a twist in the angle between the planes of the two $\pi$ systems so that they do not come together in a hinge like configuration as observed in the NNRTI X-ray structures. ${ }^{11}$ In compounds 14a and 9d the planes of the $\pi$ systems are practically orthogonal and in compound 9a these planes are nearly parallel. The ring nitrogen of compound $\mathbf{1 4 a}$ was treated as an amine nitrogen in our studies although we cannot rule out the partial delocation of the nitrogen lone pair into the isothiazole ring, a phenomenon that would flatten the nitrogen. We believe, however, that with a nitrogen atom with greater $\mathrm{sp}^{2}$ character the planes of the two $\pi$ systems would become completely orthogonal as a result of unfavourable interactions between the phenyl ring and the neighbouring $\mathrm{C}-5$ methyl and $\mathrm{SO}_{2}$ groups. In the related QM96521 compounds ${ }^{5}$ the benzyl ring is able to form one of the "butterfly" wings because of the presence of the neighbouring $\mathrm{CO}$ and $\mathrm{SO}_{2}$ groups. in our case the bulky methyl groups at $\mathrm{C}-5$ replace the planar $\mathrm{CO}$ resulting in a conformational change.

We have since identified other structures related to the two heterocyclic systems described here that by molecular modelling appear to satisfy the special angular requirements necessary to adopt the "butterfly" conformation and we are currently carrying out their synthesis.

\section{EXPERIMENTAL SECTION}

General Methods. Reactions were monitored by TLC using precoated silica gel aluminium plates containing a fluorescent indicator (Merck, 5539). Detection was done by UV (254 nm) followed by charring with sulfuric-acetic acid spray, $1 \%$ aqueous potassium permanganate solution or $0.5 \%$ phosphomolybdic acid in 95\% EtOH. Anhydrous $\mathrm{MgSO}_{4}$ was used to dry organic solutions during workups and the removal of solvents was carried out under vacuum with a rotary evaporator. Flash column chromatography was performed using Kieselgel 60 (230-400 mesh, Merck) and hexane-ethyl acetate mixtures as eluent unless otherwise stated. Optical rotations were determined with a Perkin-Elmer 257 instrument. ${ }^{1} \mathrm{H}$ and ${ }^{13} \mathrm{C}$ NMR spectra were recorded with a Varian VXR-300S spectrometer, using tetramethylsilane as internal standard.

Synthesis of Compounds 2a-2c. General Method. To a solution of acetone cyanohydrin 1 in dry dichloromethane $(25 \mathrm{~mL})$ and triethylamine (1.5-2 equiv) was added dropwise the corresponding alkylsulfonylchloride ( 0.9 to 1.3 equiv) whilst maintaining the temperalure between 0 and $5{ }^{\circ} \mathrm{C}$. The reaction was allowed to reach room temperature and was stirred for the time indicated. The mixture was filtered over Celite to remove triethylamine hydrochloride and the filtrate was evaporated. Column chromatography of the residue yielded compounds $2 \mathrm{a}-2 \mathrm{c}$ as indicated.

2-Methyl-2-(methanesulfonyloxy)propionitrile (2a). ${ }^{31}$ The General Method was followed using acetone cyanohydrin ( $4.0 \mathrm{~mL}, 43.8 \mathrm{mmol}$ ), methane sulfonyl chloride ( $4.8 \mathrm{~mL}, 62.1 \mathrm{mmol}, 1.3$ equiv) and triethylamine (12 mL, $87.5 \mathrm{mmol}, 2$ equiv) to yield after flash chromatography (2:1. hexane:ethyl acetate) 
compound $2 \mathrm{a}^{31}(5.30 \mathrm{~g}, 74 \%)$ as a colourless oil: IR (film) $v 1365,1185 \mathrm{~cm}^{-1} ;{ }^{1} \mathrm{H} \mathrm{NMR}\left(\mathrm{CDCl}_{3}, 200 \mathrm{MHz}\right) \delta$

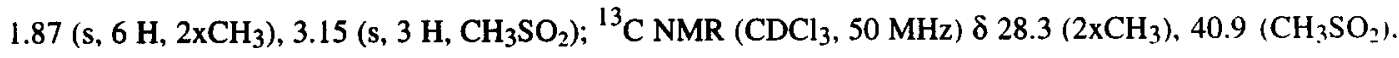
$76.07(\mathrm{C}-2), 105.1(\mathrm{CN})$.

2-Methyl-2-(ethanesulfonyloxy)propionitrile (2b). From acetone cyanohydrin $(4.0 \mathrm{~mL}, 43.8$ mmol), ethane sulfonyl chloride $(4.56 \mathrm{~mL}, 48.14 \mathrm{mmol}, 1.1$ equiv) and triethylamine (11 mL, $65.6 \mathrm{mmol}, 1.5$ equiv) after chromatography (3:1, hexane: ethyl acetate) was isolated $2 \mathbf{b}(4.62 \mathrm{~g}, 59 \%)$ as a viscous oil: IR (film) v 2990, 2960, 1460, 1355, 1175, 1135, $900 \mathrm{~cm}^{-1}$; ' $\mathrm{H}$ NMR $\left(\mathrm{CDCl}_{3} .200 \mathrm{MHz}\right) \delta 1.46(\mathrm{t}, 3 \mathrm{H} . J=7.4$ $\mathrm{Hz}, \mathrm{CH}_{3} \mathrm{CH}_{2}$ ), $1.89\left(\mathrm{~s}, 6 \mathrm{H}, 2 \mathrm{xCH}_{3}\right), 3.27\left(\mathrm{q}, 2 \mathrm{H}, J=7.4 \mathrm{~Hz}, \mathrm{CH}_{2} \mathrm{CH}_{3}\right) ;{ }^{3} \mathrm{C} \mathrm{NMR}\left(50 \mathrm{MHz}, \mathrm{CDCl}_{3}\right) \delta 8.0$ $\left(\mathrm{CH}_{3}-\mathrm{CH}_{2}\right), 28.3\left(2 \times \mathrm{CH}_{3}\right), 47.4\left(\mathrm{CH}_{2}-\mathrm{CH}_{3}\right), 74.7(\mathrm{C} 2), 118.3(\mathrm{CN})$; MS $(70 \mathrm{eV}) \mathrm{m} / \mathrm{z} 162\left(\mathrm{M}^{+}-15,7\right), 151$ $\left(M^{+}-26,19\right), 139(2), 111(17), 93(3), 83(11), 68(100), 43$ (46). Anal. Calcd for $\mathrm{C}_{6} \mathrm{H}_{1} \mathrm{NO}_{3} \mathrm{~S}: \mathrm{C}, 40.67: \mathrm{H}$. $6.26 ; \mathrm{N}, 7.90 ; \mathrm{S}, 18.09$. Found: C, 40.47; H, 6.18; N, 7.77; S, 18.29.

2-Methyl-2-(phenylmethanesulfonyloxy)propionitrile (2c). From acetone cyanohydrin ( 1.05 $\mathrm{mL}, 11.54 \mathrm{mmol}, 1.1$ equiv), $\alpha$-toluene sulfonyl chloride $(2.0 \mathrm{~g}, 10.49 \mathrm{mmol}, 1.0$ equiv) and triethylamine ( $2.63 \mathrm{~mL}, 15.7 \mathrm{mmol}, 1.5$ equiv) in dichloromethane $(30 \mathrm{~mL})$ after column chromatography $(3: 1$, hexane: ethyl acetate), the phenylmethyl sulfonate derivative $2 \mathrm{c}(1.70 \mathrm{~g}, 68 \%)$ was isolated as colourless crystals: mp. $80-81$ ${ }^{\circ} \mathrm{C}$ (toluene); IR (KBr) v 3060, 1370, 1180, $1135,910 \mathrm{~cm}^{-1} ;{ }^{1} \mathrm{H} \mathrm{NMR}\left(\mathrm{CDCl}_{3}, 200 \mathrm{MHz}\right) \delta 1.82$ (s. $6 \mathrm{H}$.

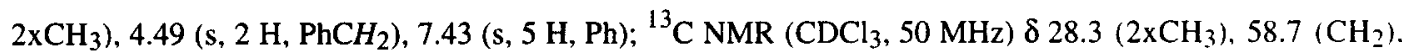
$105.2(\mathrm{CN}), 114.0(\mathrm{C} 2), 129.0,129.4,130.8,139.2(\mathrm{Ph})$. Anal. Calcd for $\mathrm{C}_{11} \mathrm{H}_{13} \mathrm{NO}_{3} \mathrm{~S}: \mathrm{C}, 55.21 ; \mathrm{H}, 5.48$ N, 5.85; S, 13.40. Found: C, 55.33; H, 5.25; N, 5.67; S, 13.31 .

4-Amino-5,5-dimethyl-1,2-oxathiole 2,2-dioxide (3a). To a solution of 2 a (11.6 g, 71.1 mmol) in dry actetonitrile $(50 \mathrm{~mL})$ was added $\mathrm{DBU}(2.67 \mathrm{~mL}, 17.8 \mathrm{mmol}, 0.25$ equiv), the reaction was stirred at $\mathrm{rt}$ for $20 \mathrm{~h}$. After evaporation of the solvent the residue was subjected to flash chromatography $(20: 1$. dichloromethane: methanol) to give a white solid which was recrystallised from dichloromethane: acetone, $2: 1$. as colourless plates $(7.99 \mathrm{~g}, 69 \%)$ : $\mathrm{mp} 175-176{ }^{\circ} \mathrm{C}$; $\mathrm{IR}(\mathrm{KBr}) \cup 3340,3380,3230,3150,1660,1620,1350$. $1190 \mathrm{~cm}^{-1}$; ${ }^{1} \mathrm{H}$ NMR (DMSO-d $\left.6,200 \mathrm{MHz}\right) \delta 1.54$ (s, $6 \mathrm{H}, 2 \mathrm{xCH}_{3}$ ), 5.34 (s, $1 \mathrm{H}, \mathrm{H} 3$ ), 6.74 (br s. 2 H. $\mathrm{NH}_{2}$ ); ${ }^{13} \mathrm{C}$ NMR (DMSO-d $\left.6,50 \mathrm{MHz}\right) \delta 25.6\left(2 \mathrm{xCH}_{3}\right), 83.8(\mathrm{C} 3), 87.1$ (C5), $160.7(\mathrm{C} 4) ; \mathrm{MS}(70 \mathrm{eV}) \mathrm{m} / \mathrm{s}$ $163\left(\mathrm{M}^{+}, 37\right), 148(71), 120(2), 70(3), 68(4), 59(37), 41(100)$. Anal. Calcd for $\mathrm{C}_{5} \mathrm{H}_{9} \mathrm{NO}_{3} \mathrm{~S}: \mathrm{C} .36 .80: \mathrm{H}$. $5.56 ; \mathrm{N}, 8.58 ; \mathrm{S}, 19.65$. Found: C, 36.84; H, 5.62; N, 8.63; S, 19.49.

4-Amino-5,5-dimethyl-3-methyl-1,2-oxathiole 2,2-dioxide (3b). Compound $2 \mathrm{~b}(0.47 \mathrm{~g}$. $2.65 \mathrm{mmol})$ in dry THF (12 mL) was stirred with $60 \% \mathrm{NaH}$ dispersion in oil $(0.13 \mathrm{~g}, 3.18 \mathrm{mmol}, 1.2$ equiv) for three hours at $\mathrm{rt}$. Water was added slowly to destroy the excess of hydride and the mixture was extracted with ethyl acetate $(3 \times 30 \mathrm{~mL})$. The dried organic layer $\left(\mathrm{MgSO}_{4}\right)$ was evaporated to yield a white solid which was recrystallised from ethyl acetate as colourless plates $(0.336 \mathrm{~g}, 71 \%)$ : $\mathrm{mp} 171-172{ }^{\circ} \mathrm{C}$; IR (KBr) v 3340.3380. 3230, 3150, 1660, 1620, 1350, $1190 \mathrm{~cm}^{-1}$; ${ }^{\mathrm{H}} \mathrm{NMR}$ (DMSO-d $\left.\mathrm{d}_{6}, 200 \mathrm{MHz}\right) \delta 1.49\left(\mathrm{~s}, 6 \mathrm{H}, 2 \mathrm{xCH}_{3}\right), 1.72$ (s, $3 \mathrm{H}, \mathrm{CH}_{3}$ ), 5.66 (br s, $2 \mathrm{H}, \mathrm{NH}_{2}$ ); ${ }^{13} \mathrm{C}$ NMR (DMSO-d, $\left.50 \mathrm{MHz}\right) \delta 5.5\left[\mathrm{CH}_{3}-(\mathrm{C} 3)\right], 25.8\left(2 \mathrm{CH}_{3}\right) .86 .4$ (C5), 90.4 (C3), 154.0 (C4); MS (70 eV) m/z $177\left(\mathrm{M}^{+}, 87\right), 162(100), 113(3), 98(15), 82(7), 55(88), 43$ (84). Anal. Calcd for $\mathrm{C}_{6} \mathrm{H}_{11} \mathrm{NO}_{3} \mathrm{~S}: \mathrm{C}, 40.67 ; \mathrm{H}, 6.26 ; \mathrm{N}, 7.90 ; \mathrm{S}, 18.09$. Found: C, 40.57: 1 , $6.11: \mathrm{N}$. 7.82: S, 18.22 . 
4-Amino-5,5,-dimethyl-3-phenyl-1,2-oxathiole 2,2-dioxide (3c). To a solution of compound $2 \mathrm{c}(1.32 \mathrm{~g}, 5.51 \mathrm{mmol})$ in acetonitrile $(15 \mathrm{~mL})$ was added DBU $(0.05 \mathrm{~mL}, 0.55 \mathrm{mmol}, 0.1$ equiv). the reaction was stirred at $\mathrm{rt}$ for $1 \mathrm{~h}$. The solvent was removed and compound $3 \mathrm{c}(1.11 \mathrm{~g}, 84 \%)$ was obtained by recrystallisation from ethyl acetate: $\mathrm{mp} 192-193^{\circ} \mathrm{C}$ : IR $(\mathrm{KBr}) \cup 3340,3380,3230,3150,1660,1620.1350$. $1190 \mathrm{~cm}^{-1}$; ${ }^{1} \mathrm{H}$ NMR (DMSO-d $\left.\mathrm{d}_{6}, 200 \mathrm{MHz}\right) \delta 1.69\left(\mathrm{~s}, 6 \mathrm{H}, 2 \mathrm{xCH}_{3}\right), 6.12$ (br s, $2 \mathrm{H}, \mathrm{NH}_{2}$ ), 7.27-7.54 (m. 5 $\mathrm{H}, \mathrm{Ph}) ;{ }^{13} \mathrm{C}$ NMR (DMSO-d 6 , $50 \mathrm{MHz}$ ) $\delta 25.8\left(2 \mathrm{xCH}_{3}\right), 85.8$ (C.5), 128.2 (C.3), 128.3,128.5, 129.4. 129.8 $(\mathrm{Ph}), 154.4$ (C4); MS (70 eV) m/z $239\left(\mathrm{M}^{+}, 100\right), 174$ (3), 160 (29), 158 (48), 106 (27). 118 (32). 89 (43). 43 (55). Anal. Calcd for $\mathrm{C}_{11} \mathrm{H}_{13} \mathrm{NO}_{3} \mathrm{~S}: \mathrm{C}, 55.21 ; \mathrm{H}, 5.48 ; \mathrm{N}, 5.85: \mathrm{S}, 13.40$. Found: C, $55.11: \mathrm{H} .5 .22: \mathrm{N}$. $5.66 ; \mathrm{S}, 13.31$.

5,5-Dimethyl-1,2-oxathiole-4-one 2,2-dioxide (4). ${ }^{20}$ A solution of 3a (162 mg. $0.99 \mathrm{mmol}$ ) was stirred in a solution of ethanol saturated with $\mathrm{HCl}(2 \mathrm{~mL})$ for $5 \mathrm{~min}$. The mixture was filtered over Celite and the filtrate was evaporated to leave a solid residue that upon recrystallisation from hexane: toluene (2:1) gave 4 ( $105.4 \mathrm{mg}, 65 \%$ ) as colourless plates $\left(\mathrm{mp} 58-59^{\circ} \mathrm{C}\right.$, lit ${ }^{20} \mathrm{mp} 59{ }^{\circ} \mathrm{C}$ ). The proton spectrum of this compound was identical to that published.

4-N-acetylamino-5,5-dimethyl-1,2-oxathiole 2,2-dioxide (5a). Compound 3a $1400 \mathrm{mg}$. $2.82 \mathrm{mmol})$ was dissolved in dry acetonitrile $(25 \mathrm{~mL})$ to which was added $4-N, N$-dimethylaminopyridine (DMAP) (1.73 g, $14.1 \mathrm{mmol}, 5$ equiv) and acetic anhydride $(0.8 \mathrm{~mL}, 3.0$ equiv), the reaction was stirred at it for $18 \mathrm{~h}$. The solvent was removed and the residues were purified by chromatography (20:1 DCM:MeOH) 10 yield $5 \mathbf{a}(117.5 \mathrm{mg}, 23 \%)$ and unreacted $3 \mathbf{a}(187.5 \mathrm{mg})$. Compound $5 \mathbf{a}$ was recrystallised from acetone as large colourless plates: $\mathrm{mp} 140-142{ }^{\circ} \mathrm{C}(\mathrm{dec})$; IR $(\mathrm{KBr}) \cup 3340,3380,3230,3150,1730.1710,1650.1540$. 1340, 1210, $1130 \mathrm{~cm}^{-1}$ : ${ }^{1} \mathrm{H}$ NMR (DMSO-d, $\left.200 \mathrm{MHz}\right) \delta 1.60\left(\mathrm{~s}, 6 \mathrm{H}, 2 \mathrm{xCH}_{3}\right) .2 .13\left(\mathrm{~s}, 3 \mathrm{H}_{1} \mathrm{CH}_{3} \mathrm{CO}\right.$ ). 7.16 (s. $1 \mathrm{H}, \mathrm{H} 3$ ). 10.15 (br s, $1 \mathrm{H}, \mathrm{NH}$ ); ${ }^{13} \mathrm{C}$ NMR (DMSO-d, $\left.50 \mathrm{MHz}\right) \delta 23.6\left(\mathrm{CH}_{3} \mathrm{CO}\right), 25.3\left(2 \mathrm{xCH}_{3}\right) .88 .2$ (C5), 100.6 (C3), 149.5 (C4), $170.5\left(\mathrm{CH}_{3} \mathrm{CO}\right)$. Anal. Calcd for $\mathrm{C}_{7} \mathrm{H}_{11} \mathrm{NO}_{4} \mathrm{~S}: \mathrm{C} .40 .97 ; \mathrm{H}, 5.40$ : N. 6.82: S. 15.62. Found: C, 40.86; H, $5.31 ; \mathrm{N}, 6.75 ; \mathrm{S}, 15.44$.

4- $\boldsymbol{N}$-Benzoylamino-5,5-dimethyl-1,2-oxathiole 2,2-dioxide (5b). Compound 3a $0.52 \mathrm{~g}$. $3.19 \mathrm{mmol})$, DMAP ( $0.58 \mathrm{~g}, 4.78 \mathrm{mmol}, 1.5$ equiv) and benzoyl chloride $(0.64 \mathrm{~mL}, 5.57 \mathrm{mmol}$, 1.75 equiv) were stirred in dry acetonitrile $(15 \mathrm{~mL})$ for $19 \mathrm{~h}$ at $\mathrm{rt}$. The solvent was evaporated and the residue was purified by flash chromatography (2:1, hexane: ethyl acetate) to yield a mixture of $3 \mathbf{a}$ and $\mathbf{5 b}$ (200 $\mathrm{mg} ; 3: 1$ ) and then pure $5 \mathrm{~b}$ ( $340.9 \mathrm{mg}, 40 \%$ yield). Recrystallisation of $\mathbf{5 b}$ from acetone gave large crystals: $\mathrm{mp} 166-167 \mathrm{C}$ (sublim); IR (KBr) v 3600-3300, 3195, 2990, 1760, 1635, 1600, 1340, 1215, 1110, 1020.890 $\mathrm{cm}^{-1}$ : ' $\mathrm{H}$ NMR (acetone $\left.\mathrm{d}_{6}, 200 \mathrm{MHz}\right) \delta 1.80\left(\mathrm{~s}, 6 \mathrm{H}, 2 \mathrm{xCH}_{3}\right), 7.33(\mathrm{~s}, 1 \mathrm{H}, \mathrm{H} 3), 7.63-7.80(\mathrm{~m}, 6 \mathrm{H}, \mathrm{Ph}+\mathrm{NH}):{ }^{13} \mathrm{C}$ NMR (acetone $\left.\mathrm{d}_{6}, 50 \mathrm{MHz}\right) \delta 25.5\left(2 \mathrm{xCH}_{3}\right), 88.6(\mathrm{C} 5), 106.0(\mathrm{C} 3), 130.0,131,3,135.8(\mathrm{Ph}), 159.8(\mathrm{C} 4)$. 162.4 (PhCO); MS (70 eV) m/z $105(100), 77$ (48), 51 (16). Anal. Calcd for $\mathrm{C}_{12} \mathrm{H}_{13} \mathrm{NO}_{4} \mathrm{~S}: \mathrm{C}, 53.92: \mathrm{H} .4 .90$ ; N, 5.24; S, 11.99. Found: C, 53.87; H, 4.86 ; N, 5.31; S, 11.87.

4- $N$-Benzylamino-5,5-dimethyl-1,2-oxathiole-2,2 dioxide (6a). A solution of $3 a(0.265 \mathrm{~g}$, $1.62 \mathrm{mmol})$ and benzylamine $(0.53 \mathrm{~mL}, 4.86 \mathrm{mmol}, 3$ equiv) in ethanol $(10 \mathrm{~mL})$ were refluxed for four days until TLC analysis indicated the complete disappearance of $3 \mathbf{a}$. The solvent was removed and the product was purified by column chromatography (1:1, hexane: ethyl acetate) as a colourless solid $(230 \mathrm{mg} .56 \%)$. Recrystallisation from toluene yielded pure $6 \mathrm{a}$ as colourless needles: $\mathrm{mp} 164-165^{\circ} \mathrm{C} ; \mathrm{IR}(\mathrm{KBr})$ v 3340,3120 . 
2990. 1625, 1550, 1295, $1125 \mathrm{~cm}^{-1} ;{ }^{1} \mathrm{H}$ NMR (DMSO-d 6 , $\left.200 \mathrm{MHz}\right) \delta 1.58\left(\mathrm{~s}, 6 \mathrm{H}, 2 \mathrm{xCH}_{3}\right.$ ), 4.21 (d. $2 \mathrm{H}$. $\mathrm{CH}_{2}-\mathrm{NH}, J=5.2 \mathrm{~Hz}$ ), 5.50 (s.1 H, H3), 7.10-7.35 (m. $5 \mathrm{H}$. Ph), 7.53 (br t, $\left.1 \mathrm{H}, \mathrm{NH}-\mathrm{CH}_{2}\right) ;{ }^{13} \mathrm{C} \mathrm{NMR}$ (DMSO-d 6 , $50 \mathrm{MHz}) \delta 26.0\left(2 \mathrm{xCH}_{3}\right), 47.8\left(\mathrm{NCH}_{2} \mathrm{Ph}\right), 83.4$ (C3), 87.1 (C5), 127,4 128.2. 129.0. 135.6 (Ph), $160.4(\mathrm{C} 4)$ : MS $(70 \mathrm{eV}) \mathrm{m} / \mathrm{z} 253\left(\mathrm{M}^{+}, 4\right), 174(16), 131$ (14), 91 (100). 65 (20). Anal. Calcd for $\mathrm{C}_{12} \mathrm{H}_{15} \mathrm{NO}_{3} \mathrm{~S}: \mathrm{C}, 56.90 ; \mathrm{H}, 5.97 ; \mathrm{N}, 5.53 ; \mathrm{S}, 12.66$. Found: C, 56.83; H, $5.74 ; \mathrm{N}, 5.25 ; \mathrm{S}, 12.38$.

4- $\boldsymbol{N}$-(2,4-Dimethoxy)benzylamino-5,5-dimethyl-1,2-oxathiole 2,2-dioxide (6b). A solution of 3a ( $103 \mathrm{mg}, 0.63 \mathrm{mmol}$ ) and 2,4-dimethoxybenzylamine hydrochloride (142 $\mathrm{mg}, 0.70 \mathrm{mmol}, 1.1$ equiv) in ethanol $(10 \mathrm{~mL})$ was refluxed for four days; TLC indicated that the reaction was not complete. The solvent was removed and the residue was purified by chromatography (1:1, hexane: ethyl acetate) to yield $6 \mathbf{b}$ $(54.4 \mathrm{mg}, 23 \%)$ as a white solid and unreacted $3 \mathrm{a}(71.9 \mathrm{mg})$. Compound $6 \mathrm{~b}$ was recrystallised from acetone as colourless needles: $\mathrm{mp} 186-188^{\circ} \mathrm{C}$; IR (KBr) $\cup 3340,3120,2990,1625,1550,1295,1125 \mathrm{~cm}^{-1}:{ }^{1} \mathrm{H}$ NMR (DMSO-d 6 , $200 \mathrm{MHz}) \delta 1.55\left(\mathrm{~s}, 6 \mathrm{H}, 2 \mathrm{xCH}_{3}\right), 3.75,3.79\left(\mathrm{~s}, \mathrm{~s}, 2 \times 3 \mathrm{H}, 2 \mathrm{xCH}_{3} \mathrm{O}\right), 4.04\left(\mathrm{~d}, 2 \mathrm{H}, \mathrm{NCH}_{2} . J=\right.$ $5.3 \mathrm{~Hz}$ ), 5.39 (s, $1 \mathrm{H}, \mathrm{H} 3), 6.51$ (dd, $1 \mathrm{H}, \mathrm{H}^{\prime} 5^{\prime}, J_{5^{\prime}, 6^{\prime}}=8.3 \mathrm{~Hz}, J_{3}^{\prime} .5^{\prime}=2.3 \mathrm{~Hz}$ ), 6.57 (d, $\left.1 \mathrm{H}, \mathrm{H} 3^{\prime}\right), 7.12$ (d, $\left.1 \mathrm{H}, \mathrm{H}-6^{\prime}\right), 7.25$ (br t, $\left.1 \mathrm{H}, \mathrm{NH}\right) ;{ }^{13} \mathrm{C}$ NMR (DMSO-d 6 , $\left.50 \mathrm{MHz}\right) \delta 25.8\left(2 \mathrm{xCH}_{3}\right), 42.9\left(\mathrm{NCH}_{2}\right), 55.1,55.4$ (2xCH 3 O), 82.5 (C3), 87.0 (C5), 98.4, 104.5, 116.8, 129.4, 160.1, 160.2 (aromatic), 158.1 (C4): MS (70 eV) $m / 2313\left(\mathrm{M}^{+}, 233(5), 151(100), 121(26), 91(11), 77(10), 43(10)\right.$. Anal. Calcd for $\mathrm{C}_{14} \mathrm{H}_{19} \mathrm{NO}_{5} \mathrm{~S}$ : C. 53.66; H. $6.11 ;$ N, 4.47; S, 10.23. Found: C, 53.47; H, 6.08 ; N, 4.32; S, 10.17 .

4-N-(2-Phenylethyl)amino-5,5-dimethyl-1,2-oxathiole 2,2-dioxide (6c). Compound 3a $(0.367 \mathrm{~g}, 2.24 \mathrm{mmol})$ and 2-phenylethylamine $(0.706 \mathrm{~mL}, 5.62 \mathrm{mmol}, 2.5$ equiv) in ethanol $(25 \mathrm{~mL})$ was refluxed for 3 days. The solvent was removed and the residue was purified by column chromatography $(1: 1$. hexane:ethyl acetate) to obtain $6 \mathrm{c}(350.8 \mathrm{mg}, 58 \%)$ as a white solid which was recrystallised from toluene as

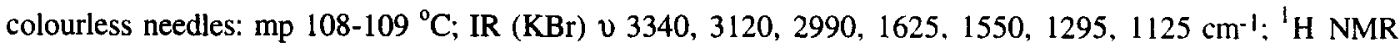
(DMSO-d $\left.{ }_{6}, 200 \mathrm{MHz}\right) \delta 1.49\left(\mathrm{~s}, 6 \mathrm{H}, 2 \mathrm{xCH}_{3}\right), 2.78\left(\mathrm{~m}, 2 \mathrm{H}, \mathrm{PhCH}_{2} \mathrm{CH}_{2}\right), 3.21$ (m, $2 \mathrm{H}, \mathrm{NHCH}_{2} \mathrm{CH}_{2} \mathrm{Ph}$ ). $5.61(\mathrm{~s}, 1 \mathrm{H}, \mathrm{H} 3), 7.01(\mathrm{br} \mathrm{m}, 1 \mathrm{H}, \mathrm{NH}), 7.2(\mathrm{~m}, 5 \mathrm{H}, \mathrm{Ph}) ;{ }^{13} \mathrm{C}$ NMR (DMSO-d, $\left.50 \mathrm{MHz}\right) \delta 26.2\left(2 \mathrm{xCH}_{3}\right)$. $33.6\left(\mathrm{PhCH}_{2} \mathrm{CH}_{2}\right), 46.1\left(\mathrm{PhCH}_{2} \mathrm{CH}_{2} \mathrm{NH}\right), 82.6(\mathrm{C} 3), 86.8(\mathrm{C} 5), 126.2,128.2,128.8,138.9(\mathrm{Ph}) .159 .9$ (C4); MS (70 eV) m/z $268(\mathrm{M}+1+4), 176(54), 145$ (31), 105 (100), 91 (47), 77 (29), 65 (22), 43 (32). Anal. Calcd for $\mathrm{C}_{13} \mathrm{H}_{17} \mathrm{NO}_{3} \mathrm{~S}: \mathrm{C}, 58.41 ; \mathrm{H}, 6.41 ; \mathrm{N}, 5.24 ; \mathrm{S}, 11.99$. Found: $\mathrm{C}, 58.37 ; \mathrm{H}, 6.28 ; \mathrm{N}, 5.08: \mathrm{S} .11 .86$

2-Benzoyloxymethyl-2-methanesulphonyloxypropionitrile (8d). Compound $7 \mathrm{~b}^{25}$ ( $5.44 \mathrm{~g}$. $30.52 \mathrm{mmol})$ in diethyl ether $(100 \mathrm{~mL})$ was stirred rapidly with a solution of $\mathrm{NaCN}(2.59 \mathrm{~g}, 39.7 \mathrm{mmol} .1 .3$ equiv) and $\mathrm{NaHCO}_{3}(5.11 \mathrm{~g}, 61 \mathrm{mmol}, 2.0$ equiv) in water for $48 \mathrm{~h}$ at $\mathrm{rt}$. The organic layer was separated and the aqueous phase was extracted with ethyl acetate $(3 \times 30 \mathrm{~mL})$. The combined organic layers were dried $\left(\mathrm{Na}_{2} \mathrm{SO}_{4}\right)$ and evaporated. The residue was purified by flash chromatography to yield first unreacted $7 \mathbf{b} \mathbf{2} .02$ g) and then the cyanohydrin $(3.07 \mathrm{~g}, 78 \%)$ as a colourless oil [ ${ }^{1} \mathrm{H}$ NMR $\left(\mathrm{CDCl}_{3}, 200 \mathrm{MHz}\right) \delta 1.65$ (s. $3 \mathrm{H}$. $\left.\left.\mathrm{CH}_{3}\right), 4.45\left(\mathrm{~s}, 2 \mathrm{H}, \mathrm{CH}_{2}\right), 7.40-8.20(\mathrm{~m}, 5 \mathrm{H}, \mathrm{Ph})\right]$ that, without further analysis, was transformed into compound $8 \mathrm{~d}$ as follows. The cyanohydrin $(0.84 \mathrm{~g}, 4.09 \mathrm{mmol})$ in $\mathrm{CH}_{2} \mathrm{Cl}_{2}(20 \mathrm{~mL})$ was stirred with triethylamine ( $2.27 \mathrm{~mL}, 16.37 \mathrm{mmol}, 4.0$ equiv) and methanesulfonyl chloride $(0.64 \mathrm{~mL}, 8.19 \mathrm{mmol}, 2.0$ equiv) for $21 \mathrm{~h}$ at rt. The mixture was filtered over Celite-545 and evaporated. Column chromatography (3:1. hexane:ethyl acetate) yielded $8 \mathrm{~d}$ as a pale yellow syrup $(0.95 \mathrm{~g}, 82 \%)$ which gave colourless needles upon standing: $\mathrm{mp} 86-87^{\circ} \mathrm{C}$ (from hexane:ethyl acetate, 5:2; colourless needles); ${ }^{1} \mathrm{H}$ NMR (DMSO- $\mathrm{d}_{6}, 200 \mathrm{MHz}$ ) $\delta$ 
$2.00\left(\mathrm{~s}, 3 \mathrm{H}, \mathrm{CH}_{3}\right), 3.47\left(\mathrm{~s}, 3 \mathrm{H}, \mathrm{CH}_{3} \mathrm{SO}_{2}\right), 4.80\left(\mathrm{~s}, 2 \mathrm{H}, \mathrm{CH}_{2}-\mathrm{O}\right), 7.55-8.13(\mathrm{~m}, 5 \mathrm{H}, \mathrm{Ph}): \mathrm{MS}(70 \mathrm{eV}) \mathrm{m} / \mathrm{s}$ $283\left(\mathrm{M}^{+}, 5\right), 188(3), 105(100), 77$ (45), 51 (17). Anal. Calcd for $\mathrm{C}_{12} \mathrm{H}_{13} \mathrm{NO}_{5} \mathrm{~S}: \mathrm{C}, 50.88: \mathrm{H}, 4.63 ; \mathrm{N} .4 .94$ : S, 11.32. Found: C, $50.67 ; \mathrm{H}, 4.57 ; \mathrm{N}, 4.77 ; \mathrm{S}, 11.23$.

General Method for the Synthesis of Compounds 9a-9c. Benzylmethyl ketone 7a $8.0 \mathrm{~g}$. $59.6 \mathrm{mmol})$ in diethyl ether $(50 \mathrm{~mL})$ was stirred rapidly so as to form an emulsion with a solution of potassium cyanide ( $5.05 \mathrm{~g}, 77.5 \mathrm{mmol}, 1.3$ equiv) and sodium hydrogen carbonate ( $10 \mathrm{~g}, 0.119 \mathrm{~mol}, 2.0$ equiv) in water $(25 \mathrm{~mL})$ for $40 \mathrm{~h}$ at $\mathrm{rt}$. The crude product was extracted with diethyl ether $(3 \times 50 \mathrm{~mL})$, the ether was dried $\left(\mathrm{MgSO}_{4}\right)$ and was evaporated to yield a pale yellow oil $(9.09 \mathrm{~g})$ which contained crude cyanohydrin and unreacted 7a. Due to the potential unstability of the cyanohydrin and since the $\mathrm{R} f$ values of the two products were similar, this crude mixture was used directly for the synthesis of compounds 9a-9c. The crude mixture was dissolved in dichloromethane $(30 \mathrm{~mL}$ ) containing triethylamine (approx. 3 times excess based on $100 \%$ conversion of $7 \mathbf{a}$ ) and was treated with the appropriate sulfonyl chloride (2 equiv). The reaction mixture was stirred for $3 \mathrm{~h}$, was filtered over Celite-545 and passed rapidly through a short flash chromatography column (2:1. hexane:ethyl acetate) to remove insoluble material. The crude mixture of $7 \mathbf{a}$ and $\mathbf{8 a} \cdot \mathbf{c}$ thus obtained was dissolved in dry acetonitrile $(50 \mathrm{~mL})$, sodium hydride ( 1.5 equiv) was added and the reaction was stirred at it until TLC analysis revealed the complete disappearance of 8 . Water $(25 \mathrm{~mL})$ was added and the mixture was extracted with dichloromethane $(3 \times 35 \mathrm{~mL})$. The organic extracts were combined, dried $\left(\mathrm{MgSO}_{4}\right)$ and evaporated to leave an oil that was purified by flash chromatography to give the final products $9 \mathbf{a}-\mathbf{c}$.

4-Amino-5-methyl-5-phenylmethyl-1,2-oxathiole 2,2-dioxide (9a). Column chromalography (2:1, hexane: ethyl acetate) gave $9 \mathbf{a}(0.54 \mathrm{~g}, 17 \%$ from $7 \mathbf{a})$ which was recrystallised from dichloromethane:methanol (9:1) as colourless plates: $\mathrm{mp} 196-198^{\circ} \mathrm{C}$; ${ }^{1} \mathrm{H}$ NMR (DMSO- $\left.\mathrm{d}_{6}, 200 \mathrm{MHz}\right) \delta 1.45(\mathrm{~s}$. $3 \mathrm{H}, \mathrm{CH}_{3}$ ), 3.10 (s. $2 \mathrm{H}, \mathrm{CH}_{2}$ ), 5.28 (s, 2H, H-3), 6.80 (bs, 2H, $\left.\mathrm{NH}_{2}\right) 7.20-7.23$ (m, 5II. Ph): ${ }^{13} \mathrm{C}$ NMR 150 MHz, DMSO-d $\left.{ }_{6}\right) \delta 23.84\left(\mathrm{CH}_{3}\right), 42.67\left(\mathrm{CH}_{2}\right), 84.9(\mathrm{C}-3), 88.8(\mathrm{C}-5), 126.8,127.8,130.5 .134 .7(\mathrm{Ph})$. 159.5 (C-4). Anal. Calcd. for $\mathrm{C}_{11} \mathrm{H}_{13} \mathrm{NO}_{3} \mathrm{~S}: \mathrm{C}, 55.21 ; \mathrm{H}, 5.48 ; \mathrm{N}, 5.85 ; \mathrm{S}, 13.40$. Found: C, $55.11: \mathrm{H}, 5.32$ : N. 5.67; S, 13.21 .

4-Amino-2,5-dimethyl-5-phenylmethyl-1,2-oxathiole 2,2-dioxide (9b).

Flash chromatography $(2: 1-1: 2$, hexane:ethyl acetate) gave $9 \mathbf{b}(1.19 \mathrm{~g}, 15 \%$ from $7 \mathbf{a})$ : this was recrystallised from toluene as colourless plates: $\mathrm{mp} 146-147^{\circ} \mathrm{C}$; $\mathrm{IR}(\mathrm{KBr}) \cup 3340,3120,2990,1625,1550,1295,1125 \mathrm{~cm}^{-1}:{ }^{1} \mathrm{H}$ NMR (DMSO-d $\left.{ }_{6}, 200 \mathrm{MHz}\right) \delta 1.42\left(\mathrm{~s}, 3 \mathrm{H}, \mathrm{CH}_{3}\right), 1.68$ (s. $\left.3 \mathrm{H}, \mathrm{CH}_{3} \mathrm{C} 3\right), 3.06$ (d, $1 \mathrm{H} . J=12.6 \mathrm{~Hz}$. $\mathrm{CH}_{2} \mathrm{Ph}$ ), $3.16\left(\mathrm{~d}, 1 \mathrm{H}, J=12.6 \mathrm{~Hz}, \mathrm{CH}_{2} \mathrm{Ph}\right), 6.42$ (br s, $\left.2 \mathrm{H}, \mathrm{NH}_{2}\right), 7.20-7.30(\mathrm{~m}, 5 \mathrm{H}, \mathrm{Ph}) ;{ }^{1.3} \mathrm{C}$ NMR (DMSO-d 6 , $50 \mathrm{MHz}) \delta 5.4\left(\mathrm{CH}_{3} \mathrm{C} 3\right), 23.7\left(\mathrm{CH}_{3} \mathrm{C} 5\right), 42.9\left(\mathrm{PhCH}_{2}\right), 88.0$ (C5), 91.3 (C3), 121.3. 126.8. 127.8, 130.5, $134.8(\mathrm{Ph}), 152.9(\mathrm{C} 4)$. Anal. Calcd for $\mathrm{C}_{12} \mathrm{H}_{15} \mathrm{NO}_{3} \mathrm{~S}: \mathrm{C}, 56.90 ; \mathrm{H}, 5.97 ; \mathrm{N}, 5.53: \mathrm{S} .12 .66$. Found: C, 56.78; H, 5.72; N, 5.33; S, 12.43.

4-Amino-5-methyl-3-phenyl-5-phenylmethyl-1,2-oxathiole 2,2-dioxide (9c). Purification by column chromatography (3:1-1:1, hexane:ethyl acetate) gave $9 \mathrm{c}(0.615 \mathrm{~g}, 21 \%$ over 3 steps from $7 \mathrm{a})$ as colourless plates from toluene: $\mathrm{mp} 160-161^{\circ} \mathrm{C}$; $\mathrm{IR}(\mathrm{KBr}) 3495,3360,3320,1655,1625,1300.1170 \mathrm{~cm}^{-1}:{ }^{1} \mathrm{H}$ NMR (DMSO-d 6 , $200 \mathrm{MHz}$ ) $\delta 1.58\left(\mathrm{~s}, 3 \mathrm{H}, \mathrm{CH}_{3}\right.$ ), 3.23 (s, $2 \mathrm{H}, \mathrm{PhCH}_{2}$ ), 6.93 (br s, $2 \mathrm{H}, \mathrm{NH}_{2}$ ). 7.20-7.45 $\left(\mathrm{m}, 10 \mathrm{H}, 2 \mathrm{Ph}\right.$ ); ${ }^{13} \mathrm{C}$ NMR (DMSO-d, $\left.50 \mathrm{MHz}\right) \delta 24.0\left(\mathrm{CH}_{3}\right), 42.9\left(\mathrm{PhCH}_{2}\right), 87.5(\mathrm{C} 5), 97.7(\mathrm{C} 3), 126.9$. 127.9. 127.9, 128.9, 130.5, $134.6(2 \times \mathrm{Ph}), 153.0(\mathrm{C} 4) ; \mathrm{MS}(70 \mathrm{eV}) \mathrm{m} / \mathrm{z} 315\left(\mathrm{M}^{+}, 27\right), 251$ (10), $234(4)$. 
224 (27), 160 (43), 117 (100), 89 (17), 65 (20), 43 (52). Anal. Calcd for $\mathrm{C}_{17} \mathrm{H}_{17} \mathrm{NO}_{3} \mathrm{~S}: \mathrm{C}, 64.74: \mathrm{H}, 5.43: \mathrm{N}$. 4.44; S, 10.17. Found: C, 64.67; H, 5.31; N, 64; S, 10.23 .

4-Amino-5-benzoyloxymethyl-5-methyl-1,2-oxathiole 2,2-dioxide (9d). Compound 8d ( $0.63 \mathrm{~g}, 2.22 \mathrm{mmol}$ ) in $\mathrm{CH}_{3} \mathrm{CN}$ (25 mL) containing DBU ( $0.23 \mathrm{~mL}, 1.55 \mathrm{mmol}, 0.7$ equiv) was stirred for 24 $\mathrm{h}$ at $\mathrm{rt}$. The solvent was removed and the residue was purified by flash chromatography (2:1, hexane:ethyl acetate-20:1. $\left.\mathrm{CH}_{2} \mathrm{Cl}_{2}: \mathrm{MeOH}\right)$ to afford $9 \mathrm{~d}(0.24 \mathrm{~g}, 54 \%)$ as a colourless solid; this was recrystallised from toluene as colourless needles: $\mathrm{mp} 188-189^{\circ} \mathrm{C}(\mathrm{dec})$; $\mathrm{IR}(\mathrm{KBr}) \cup 3470,3360,3140,1710,1650,1285.1120$. $900 \mathrm{~cm}^{-1}$; 'H NMR (DMSO, $200 \mathrm{MHz}$ ) $\delta 1.60$ (s, $3 \mathrm{H}, \mathrm{CH}_{3}$ ), 4.45, 4.70 ( $2 \mathrm{x} \mathrm{d}, 2 \mathrm{H}, J=12.5 \mathrm{~Hz} . \mathrm{CH}_{2}$ ), 5.56 (s, $1 \mathrm{H}, \mathrm{H} 3$ ), 6.83 (br s. $2 \mathrm{H}, \mathrm{NH}_{2}$ ), 7.45-8.08 (m, 5 H, Ph); ${ }^{13} \mathrm{C}$ NMR (DMSO-d 6 , $\left.50 \mathrm{MHz}\right) \delta 21.2\left(\mathrm{CH}_{3}\right)$, $65.3\left(\mathrm{CH}_{2}\right), 85.9$ (C3), 87.2 (C5), 128.6, 129.0, 129.4, 135.6 (Ph), 156.7 (C4), 165.0 (CO); MS (70 eV) $\mathrm{m} / \mathrm{=}$ $283\left(\mathrm{M}^{+}, 4\right), 189(7), 174(2), 148(2), 122(4), 105(100), 77(36), 51$ (13). Anal. Calcd for $\mathrm{C}_{12} \mathrm{H}_{13} \mathrm{NO}_{5} \mathrm{~S}: \mathrm{C}$, $50.88 ; \mathrm{H}, 4.63 ; \mathrm{N}, 4.94 ; \mathrm{S}, 11.32$. Found: $\mathrm{C}, 50.65 ; \mathrm{H}, 4.75 ; \mathrm{N}, 4.79 ; \mathrm{S}, 11.43$.

2-Amino-2-methylpropionitrile $(\mathbf{1 0})^{28}$ To a mixture of ammonium chloride $(9.60 \mathrm{~g}, 180 \mathrm{mmol})$ and $30 \%$ ammonium hydroxide solution $(10 \mathrm{~mL})$ in water $(20 \mathrm{~mL})$ was added acetone $(10.3 \mathrm{~g}, 177 \mathrm{mmol})$. The reaction mixture was cooled to approximately $5{ }^{\circ} \mathrm{C}$ and solid sodium cyanide $(8.80 \mathrm{~g}, 179 \mathrm{mmol})$ was added slowly over $15 \mathrm{~min}$. The reaction was allowed to reach $\mathrm{rt}$ and was stirred for $60 \mathrm{~h}$. The aqueous mixture was extracted with dichloromethane $(3 \times 50 \mathrm{~mL})$, the organic phase was dried $\left(\mathrm{MgSO}_{4}\right)$, filtered and evaporated to yield $10^{28}(12.57 \mathrm{~g}, 84.4 \%)$ as a mobile, pale yellow oil. This product was used directly for the next steps.

2-Methyl-2(methanesulfonylamido)propionitrile (11a). ${ }^{29}$ To a solution of 10 (10.0 g. 0.119 mol) and triethylamine $(24.8 \mathrm{~mL}, 0.178 \mathrm{~mol}, 1.5$ equiv. $)$ in dry dichloromethane $(150 \mathrm{~mL})$ at $0{ }^{\circ} \mathrm{C}$ was added dropwise methanesulfonyl chloride $(11.0 \mathrm{~mL}, 0.143 \mathrm{~mol}, 1.2$ equiv). The mixture was stirred at it for $16 \mathrm{~h}$. was filtered over Celite-545 and evaporated. Column chromatography (3:1, hexane:ethyl acetate) gave pure $11 \mathrm{a}^{29}(11.98 \mathrm{~g}, 62.1 \%)$ as a pale buff coloured solid; the product was recrystallised from toluene containing 2$3 \%$ EtOH as slightly off white needles: mp. $72-73{ }^{\circ} \mathrm{C}\left(\right.$ lit. $\left.{ }^{29} 72-74{ }^{\circ} \mathrm{C}\right) ;{ }^{1} \mathrm{H} \mathrm{NMR}\left(\mathrm{CDCl}_{3}, 200 \mathrm{MHz}\right) \delta 1.75$ (s. $\left.6 \mathrm{H}, 2 \mathrm{xCH}_{3}\right), 3.18$ (s, $3 \mathrm{H}, \mathrm{CH}_{3} \mathrm{SO}_{2}$ ), 5.22 (br s, $1 \mathrm{H}, \mathrm{NH}$ ).

2-Methyl-2-(ethanesulfonylamido)propionitrile (11b). Compound $10(5.0 \mathrm{~g}, 59.5 \mathrm{mmol})$ and triethylamine (11.0 mL, $71.7 \mathrm{mmol}, 1.2$ equiv) in dichloromethane $(70 \mathrm{~mL})$ was cooled to $0-5{ }^{\circ} \mathrm{C}$. ethanesulfonyl chloride ( $6.73 \mathrm{~mL}, 71.1 \mathrm{mmol}, 1.19$ equiv) was added dropwise and the solution was stirred for $2.5 \mathrm{~h}$. The solution was filtered over Celite- 545 and was evaporated, the residue was purified by flash chromatography (1:1, hexane:ethyl acetate) to yield a pale yellow syrup that crystallised upon standing. Recrystallisation (3:1, hexane:ethyl acetate) gave $11 \mathrm{~b}(2.59 \mathrm{~g}, 25 \%)$ as large colourless needles: $\mathrm{mp} 54-55{ }^{\circ} \mathrm{C}$ : ${ }^{\mathrm{l}} \mathrm{H}$ NMR $\left(\mathrm{CDCl}_{3}, 200 \mathrm{MHz}\right) \delta 1.42\left(\mathrm{t}, 3 \mathrm{H}, \mathrm{CH}_{3} \mathrm{CH}_{2} \mathrm{SO}_{2}\right), 1.73\left(\mathrm{~s}, 6 \mathrm{H}, 2 \mathrm{xCH}_{3}\right), 3.24$ (q, $2 \mathrm{H}$. $\mathrm{CH}_{3} \mathrm{CH}_{2} \mathrm{SO}_{2}$ ), 4.90 (br s, $1 \mathrm{H}, \mathrm{NH}$ ); MS (70 eV) m/z 161 (61), 150 (11), 97 (3), 81 (2), 69 (81), 56 (37), 42 (100). Anal. Calcd for $\mathrm{C}_{6} \mathrm{H}_{12} \mathrm{~N}_{2} \mathrm{O}_{2} \mathrm{~S}: \mathrm{C}, 40.89 ; \mathrm{H}, 6.86 ; \mathrm{N}, 15.90 ; \mathrm{S}, 18.19$. Found: C, 40.92: H. 6.93: N. 15.87; S, 18.05.

2-Methyl-2-(phenylmethanesulfonamido)propionitrile (11c). To a solution of $10(4.61 \mathrm{~g}$. $55.0 \mathrm{mmol}, 1.5$ equiv) and triethylamine $\left(15.2 \mathrm{~mL}, 109 \mathrm{mmol}, 3.0\right.$ equiv) in dichloromethane $(80 \mathrm{~mL})$ at $0{ }^{\circ} \mathrm{C}$ was added dropwise a solution of $\alpha$-toluenesulfonyl chloride ( $7.0 \mathrm{~g}, 36.7 \mathrm{mmol}, 1$ equiv) in dichloromethane $(70 \mathrm{~mL}$ ) over a period of $30 \mathrm{~min}$. The reaction was stirred at $\mathrm{rt}$ for $16.5 \mathrm{~h}$, was filtered over Celite-545 and was 
evaporated. Flash chromatography (3:1, hexane:ethyl acetate) yielded first unreacted $\alpha$-toluene sulfonyl chloride $(1.11 \mathrm{~g})$ and then $11 \mathrm{c}(3.46 \mathrm{~g}, 47 \%)$ as colourless needles from acetone: $\mathrm{mp} 128-129{ }^{\circ} \mathrm{C}:{ }^{1} \mathrm{H}$ NMR (acetone$\left.\mathrm{d}_{6}, 200 \mathrm{MHz}\right) \delta 1.66\left(\mathrm{~s}, 6 \mathrm{H}, 2 \mathrm{xCH}_{3}\right), 4.45$ (s, $2 \mathrm{H}, \mathrm{PhCH}_{2} \mathrm{SO}_{2}$ ), 4.56 (br s, $1 \mathrm{H}, \mathrm{NH}$ ), 7.2-7.5 (m. $5 \mathrm{H}$. $\mathrm{Ph}) ;{ }^{13} \mathrm{C}$ NMR (acetone- $\left.\mathrm{d}_{6}, 200 \mathrm{MHz}\right) \delta 29.3,31.4\left(2 \times \mathrm{C}, \mathrm{CH}_{3}\right), 60.2\left(\mathrm{PhCH}_{2} \mathrm{O}\right), 112.8(\mathrm{CN}), 129.4,129.5$. $131.4(\mathrm{Ph})$; MS (70 eV) m/z 174 (6), 159 (5), $146(2), 132$ (1), 91 (100), 65 (25). Anal. Calcd for $\mathrm{C}_{11} \mathrm{H}_{14} \mathrm{~N}_{2} \mathrm{O}_{2} \mathrm{~S}: \mathrm{C}, 55.44 ; \mathrm{H}, 5.92 ; \mathrm{N}, 11.76 ; \mathrm{S}, 13.45$. Found: $\mathrm{C}, 55.54 ; \mathrm{H}, 5.87 ; \mathrm{N}, 11.64: \mathrm{S} .13 .52$

2-Methyl-2-[ $N$-(benzyl)-methanesulfonamido]propionitrile (13a). Compound 11a $(0.42 \mathrm{~g}$. $2.58 \mathrm{mmol}$ ) was refluxed with benzyl bromide $\left(0.34 \mathrm{~mL}, 2.85 \mathrm{mmol}, 1.10\right.$ equiv) and $\mathrm{K}_{2} \mathrm{CO}_{3}$ (0.54 g. 3.88 mmol, 1.5 equiv) in $\mathrm{CH}_{3} \mathrm{CN}(20 \mathrm{~mL}$ ) for $5 \mathrm{~h}$. The mixture was filtered and evaporated, the residue was subjected to flash chromatography (3:1, hexane:ethyl acetate) to yield $13 \mathrm{a}(0.39 \mathrm{~g}, 60 \%)$ as a white solid: $\mathrm{mp}$ $87-89^{\circ} \mathrm{C}$ (from acetone); IR (KBr) $v 3040,1330,1320,1145,960 \mathrm{~cm}^{-1} ;{ }^{1} \mathrm{H} \mathrm{NMR}\left(\mathrm{CDCl}_{3} .200 \mathrm{MHz}\right) \delta 1.78$ (s, $\left.6 \mathrm{H}, 2 \mathrm{xCH}_{3}\right), 3.08\left(\mathrm{~s}, 3 \mathrm{H}, \mathrm{CH}_{3} \mathrm{SO}_{2} \mathrm{~N}\right.$ ), $4.63\left(\mathrm{~s}, 2 \mathrm{H}, \mathrm{NCH}_{2}\right), 7.30-7.50(\mathrm{~m}, 5 \mathrm{H}, \mathrm{Ph}):{ }^{13} \mathrm{C} \mathrm{NMR}$ $\left(\mathrm{CDCl}_{3}, 50 \mathrm{MHz}\right) \delta 29.1\left(\mathrm{CH}_{3}\right), 41.3\left(\mathrm{MeSO}_{2}\right), 50.7\left(\mathrm{NCH}_{2} \mathrm{Ph}\right), 55.4(\mathrm{C} 2), 120.8(\mathrm{CN}), 127.3,127.9$. 128.8, $137.4(\mathrm{Ph})$; MS (70 eV) m/z $226\left(\mathrm{M}^{+}-26,27\right), 184(10), 173(24), 157$ (30), 146 (37). 106 (41). 91 (100), 77 (13). Anal. Calcd for $\mathrm{C}_{12} \mathrm{H}_{16} \mathrm{~N}_{2} \mathrm{O}_{2} \mathrm{~S}: \mathrm{C}, 57.12 ; \mathrm{H}, 6.39 ; \mathrm{N}, 11.10 ; \mathrm{S}, 12.71$. Found: C. 57.23: $\mathrm{H}$. 6.29; N, 11.22; S, 12.87.

2-Methyl-2-[N-(4-chlorobenzyl)methanesulfonamido]propionitrile (13b). Compound $11 \mathrm{a}$ $(0.406 \mathrm{~g}, 2.50 \mathrm{mmol})$ was refluxed with 4-chlorobenzyl chloride $(0.525 \mathrm{~g}, 3.26 \mathrm{mmol} .1 .30$ equiv) and potassium carbonate $(0.514 \mathrm{~g}, 3.75 \mathrm{mmol}, 1.5$ equiv) in acetonitrile $(25 \mathrm{~mL})$ for $18 \mathrm{~h}$. After standard work-up (filtration and evaporation), the product was purified by flash chromatography $(3: 1-1: 1$, hexane:ethyl acetate) to obtain first 13b $(0.342 \mathrm{~g}, 47 \%)$ as a colourless syrup [IR (film) $v 3040,2940,1495,1335,1165 \mathrm{~cm}^{-1}:{ }^{~} \mathrm{H}$ $\operatorname{NMR}\left(\mathrm{CDCl}_{3}, 200 \mathrm{MHz}\right) \delta 1.75\left(\mathrm{~s}, 6 \mathrm{H}, 2 \mathrm{xCH}_{3}\right), 3.07\left(\mathrm{~s}, 3 \mathrm{H}, \mathrm{CH}_{3} \mathrm{SO}_{2}\right), 4.58\left(\mathrm{~s}, 2 \mathrm{H}, \mathrm{NCH}_{2}\right)$, 7.25-7.45 $(\mathrm{m}, 4 \mathrm{H}, \mathrm{Ar}) ;{ }^{13} \mathrm{C} \mathrm{NMR}\left(\mathrm{CDCl}_{3}, 50 \mathrm{MHz}\right) \delta 29.5\left(\mathrm{CH}_{3}\right), 41.3\left(\mathrm{CH}_{3} \mathrm{SO}_{2}\right), 50.3\left(\mathrm{NCH}_{2}\right), 56.0(\mathrm{C} 2), 128.8$. 129.0, 129.95, 136.0 (Ar); MS (70 eV) m/z 260, $262\left(\mathrm{M}^{+}-26,7,2\right), 218(16), 207$ (28), 191, 193 (61, 20). 180, $182(59,19), 164$ (4), 140 (45), 125 (100), 73 (12), 89 (34). Anal. Calcd for $\mathrm{C}_{12} \mathrm{H}_{15} \mathrm{ClN}_{2} \mathrm{O}_{2} \mathrm{~S}:$ C. 50.26 : H. 5.27; N, 9.77; S, 11.18; Cl, 12.36. Found: C, 50.17; H, 5.44; N, 9.98; S, 11.06; Cl. 12.45] and then the cyclised product $14 \mathrm{~b}(81.4 \mathrm{mg}, 11.3 \%)$ (see below).

2-Methyl-2-[N-(3-chlorobenzyl)methanesulfonamido]propionitrile (13c). Compound $11 \mathrm{a}$ $(0.56 \mathrm{~g}, 3.44 \mathrm{mmol})$ was refluxed with 3 -chlorobenzyl bromide $\left(0.495 \mathrm{~mL}, 3.78 \mathrm{mmol}, 1.1\right.$ equiv) and $\mathrm{K}_{2} \mathrm{CO}_{3}$ $\left(0.96 \mathrm{~g}, 6.89 \mathrm{mmol}, 2\right.$ equiv) in $\mathrm{CH}_{3} \mathrm{CN}(25 \mathrm{~mL})$ for $5.5 \mathrm{~h}$. After filtration and evaporation of the solvent. purification by column chromatography ( $3: 1$ to $1: 1$ hexane:ethyl acetate) gave $13 \mathrm{c}(0.55 \mathrm{~g}, 63.8 \%)$ as a white solid: $\mathrm{mp} 103-105^{\circ} \mathrm{C}$ (needles from acetone); IR $(\mathrm{KBr}) \cup 3040,2940,1600,1335,1165 \mathrm{~cm}^{-1}:{ }^{1} \mathrm{H}$ NMR $\left(\mathrm{CDCl}_{3}, 200 \mathrm{MHz}\right) \delta 1.78\left(\mathrm{~s}, 6 \mathrm{H}, 2 \times \mathrm{xH}_{3}\right), 3.10\left(\mathrm{CH}_{3} \mathrm{SO}_{2}\right), 4.56\left(\mathrm{NCH}_{2}\right), 7.25-7.43(\mathrm{~m}, 5 \mathrm{H} . \mathrm{Ar}):{ }^{13} \mathrm{C}$ NMR $\left(\mathrm{CDCl}_{3}, 50 \mathrm{MHz}\right) \delta 24.0\left(\mathrm{CH}_{3}\right), 41.1\left(\mathrm{CH}_{3} \mathrm{SO}_{2}\right), 50.37\left(\mathrm{NCH}_{2}\right), 55.5(\mathrm{C} 2), 125.4,127.3,128.1$. 130.0, 134.7, 139.6 (Ar); MS (70 eV) m/z $218(10), 207(23), 191(30), 180,182(45,16), 140,142(52$. 14), 125 (100), 89 (23), 75 (16), 63 (13). Anal. Calcd for $\mathrm{C}_{12} \mathrm{H}_{15} \mathrm{ClN}_{2} \mathrm{O}_{2} \mathrm{~S}: \mathrm{C}, 50.26 ; \mathrm{H}, 5.27 ; \mathrm{N}, 9.77$ : S. $11.18 ; \mathrm{Cl}, 12.36$. Found: C, 50.37; H, 5.43; N, 9.67; S, 11.33; Cl, 12.23 . 


\section{2-Methyl-2-[N-(m-chlorobenzyl)phenylmethylsulfonamido]propionitrile (13f)}

Compound $11 \mathrm{c}(0.50 \mathrm{~g}, 2.10 \mathrm{mmol})$ was refluxed with $\mathrm{K}_{2} \mathrm{CO}_{3}(0.58 \mathrm{~g}, 4.20 \mathrm{mmol}, 2.0$ equiv) and 3-chlorobenzyl bromide $(0.36 \mathrm{~mL}, 2.73 \mathrm{mmol}, 1.3$ equiv) for $3.5 \mathrm{~h}$. The mixture was filtered over Celite- 545 and was evaporated. The residue was purified by column chromatography $(2: 1$, hexane:ethyl acetate) to give first 13f $(0.480 \mathrm{~g}, 61 \%)$ : oil; IR (film) v 3080, 2940, 1600, 1345, $1150 \mathrm{~cm}^{-1}$; ' $\mathrm{H} \mathrm{NMR}\left(\mathrm{CDCl}_{3} .200 \mathrm{MHz}\right) \delta$ $1.57\left(\mathrm{~s}, 6 \mathrm{H}, 2 \mathrm{xCH}_{3}\right), 4.00\left(\mathrm{~s}, 2 \mathrm{H}, \mathrm{NCH}_{2} \mathrm{Ar}\right.$ ), $4.52\left(\mathrm{~s}, 2 \mathrm{H}, \mathrm{NSO}_{2} \mathrm{CH}_{2} \mathrm{Ph}\right.$ ), 7.20-7.50 (m, $9 \mathrm{H}$, aromat.): ${ }^{13} \mathrm{C} \mathrm{NMR}\left(\mathrm{CDCl}_{3}, 200 \mathrm{MHz}\right) \delta 29.0\left(2 \mathrm{xCH}_{3}\right), 50.8\left(\mathrm{NCH}_{2} \mathrm{Ar}\right), 55.1(\mathrm{C} 2), 60.3\left(\mathrm{NSO}_{2} \mathrm{CH}_{2} \mathrm{Ph}\right), 126.1-130.9$ (aromat.); MS (70 eV) m/z 272, 274 (4, 1), 207 (3), 180, 182 (8, 4), 173 (9), 166 (6), 140 (3). 125 (18). 91 (100), 65 (17). Anal. Calcd for $\mathrm{C}_{18} \mathrm{H}_{19} \mathrm{ClN}_{2} \mathrm{O}_{2} \mathrm{~S}: \mathrm{C}, 59.58 ; \mathrm{H}, 5.28 ; \mathrm{N}, 7.72 ; \mathrm{S}, 8.84 ; \mathrm{Cl}, 19.77$. Found: $\mathrm{C}$. 59.65; H, 5.44: N. 7.65; S. 8.91: Cl, 19.99; and then, compound $14 \mathrm{f}$ ( $82 \mathrm{mg} .10 \%$, see below).

\section{4-Amino-2-benzyl-3,3-dimethyl-2,3-dihydroisothiazole 1,1-dioxide (14a)}

Compound 13a ( $0.344 \mathrm{~g}, 1.36 \mathrm{mmol})$ and $60 \% \mathrm{NaH}$ dispersion in oil $(57 \mathrm{mg}, 1.42 \mathrm{mmol}, 1.05$ equiv) in $\mathrm{CH}_{3} \mathrm{CN}(10 \mathrm{~mL})$ was stirred at $\mathrm{rt}$ for $2 \mathrm{~h}$. Water $(10 \mathrm{~mL})$ was added and the mixture was extracted with $\mathrm{CH}_{2} \mathrm{Cl}_{2}$ $(3 \times 20 \mathrm{~mL})$. The organic solvent was dried $\left(\mathrm{MgSO}_{4}\right)$ and evaporated to give a yellowish solid $(0.48 \mathrm{~g})$ :

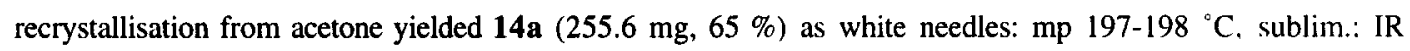
$(\mathrm{KBr}) \cup 3440,3355,3290,3240,3100,2940,1650,1600,1240,1100 \mathrm{~cm}^{-1} ;{ }^{1} \mathrm{H}$ NMR (DMSO-d $\mathrm{d}_{6}, 200 \mathrm{MHz}$ ) $\delta 1.22\left(\mathrm{~s}, 6 \mathrm{H}, 2 \mathrm{CCH}_{3}\right), 4.18\left(\mathrm{~s}, 2 \mathrm{H}, \mathrm{NCH}_{2}\right), 5.16(\mathrm{~s}, 1 \mathrm{H}, \mathrm{H} 5), 5.84$ (br s, $\left.2 \mathrm{H}, \mathrm{NH}_{2}\right), 7.20-7.60$ (m. $5 \mathrm{H}$. $\mathrm{Ph}) ;{ }^{13} \mathrm{C}$ NMR (DMSO-d, $\left.50 \mathrm{MHz}\right) \delta 23.8\left(\mathrm{CH}_{3}\right), 41.3\left(\mathrm{NCH}_{2}\right), 63.3(\mathrm{C} 3), 85.8$ (C5), 127.85. 129.0. $129.1(\mathrm{Ph}), 160.2(\mathrm{C} 4)$; MS (70 eV) m/z $237\left(\mathrm{M}^{+}-15,12\right), 187$ (6), 173 (6), $148(9), 91$ (100). 65 (15). 41 (11). Anal. Calcd for $\mathrm{C}_{12} \mathrm{H}_{16} \mathrm{~N}_{2} \mathrm{O}_{2} \mathrm{~S}: \mathrm{C}, 57.12 ; \mathrm{H}, 6.39 ; \mathrm{N}, 11.10 ; \mathrm{S}, 12.71$. Found: C, 56.92; H. 6.50; N, 11.26; S, 12.49 .

4-Amino-2-(p-chlorobenzyl)-3,3-dimethyl-2,3-dihydroisothiazole 1,1-dioxide (14b). Compound 13b $(0.305 \mathrm{~g}, 1.06 \mathrm{mmol})$ and $\mathrm{NaH}(43 \mathrm{mg} .1 .075 \mathrm{mmol}, 1.01$ equiv, 60\% dispersion in oil) in $\mathrm{CH}_{3} \mathrm{CN}(15 \mathrm{~mL})$ was stirred at $\mathrm{rt}$ for $4 \mathrm{~h}$. Water $(20 \mathrm{~mL})$ was added and the mixture was extracted with $\mathrm{CH}_{2} \mathrm{Cl}_{2}$ $(3 \times 30 \mathrm{~mL})$. Evaporation of the organic phase yielded a yellow solid which was purified by recrystallisation from ethyl acetate to give 14b as white needles: $\mathrm{mp} 221-222{ }^{\circ} \mathrm{C}$ (sublim); $\mathrm{IR}(\mathrm{KBr}) \cup 3440,3350,3290,3240$, $3100,2940,1650,1600,1240,1100 \mathrm{~cm}^{-1}$; ${ }^{1} \mathrm{H}$ NMR (DMSO-d, $200 \mathrm{MHz}$ ) $\delta 1.23$ (s. $6 \mathrm{H}, 2 \mathrm{xCH}_{3}$ ). 4.18 (s. $\left.2 \mathrm{H}, \mathrm{NCH}_{2}\right), 5.16(\mathrm{~s}, 1 \mathrm{H}, \mathrm{H} 5), 6.44$ (br s, $\left.2 \mathrm{H}, \mathrm{NH}_{2}\right), 7.40(2 \mathrm{x} \mathrm{d}, 4 \mathrm{H}, \mathrm{Ar}) ;{ }^{13} \mathrm{C}$ NMR (DMSO-d ${ }_{6}, 50 \mathrm{MHz}$ )

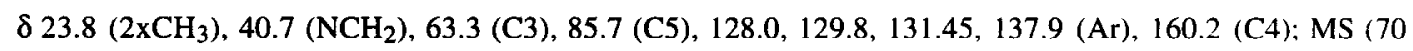
eV) $m / z 271,273\left(\mathrm{M}^{+}-15,4,1\right), 221(5), 207(5), 180,182(3,4), 125$ (100), $111(5), 99$ (4), 89 (13). Anal. Calcd for $\mathrm{C}_{12} \mathrm{H}_{15} \mathrm{ClN}_{2} \mathrm{O}_{2} \mathrm{~S}: \mathrm{C}, 50.26 ; \mathrm{H}, 5.27 ; \mathrm{N}, 9.77 ; \mathrm{S}, 11.18 ; \mathrm{Cl}, 12.36$. Found: C, 50.01: H.5.04; N 9.92: $\mathrm{S}, 10.99 ; \mathrm{Cl}, 12.06$.

4-Amino-2-(m-chlorobenzyl)-3,3-dimethy-2,3-dihydroisothiazole 1,1-dioxide (14c). Compound $13 \mathrm{c}(0.53 \mathrm{~g}, 2.13 \mathrm{mmol})$ and $\mathrm{NaH}(0.114 \mathrm{~g}, 3.58 \mathrm{mmol}, 1.7$ equiv, 60\% dispersion in oil) in $\mathrm{CH}_{3} \mathrm{CN}(10 \mathrm{~mL})$ was stirred at $\mathrm{rt}$ for $6 \mathrm{~h}$. Water $(20 \mathrm{~mL})$ was added and the mixture was extracted with dichloromethane $(3 \times 30 \mathrm{~mL})$. The dried $\left(\mathrm{MgSO}_{4}\right)$ extracts were evaporated to give a yellow solid that was recrystallised from acetone to obtain $14 \mathrm{c}(0.229 \mathrm{~g}, 43 \%)$ as pale yellow needles: $\mathrm{mp} 183-185{ }^{\circ} \mathrm{C}$ : $\mathrm{IR}(\mathrm{KBr}) \mathrm{v}$ $3440,3350,3290,3240,3100,2940,1650,1600,1240,1100 \mathrm{~cm}^{-1}$; ' $\mathrm{H}$ NMR (DMSO-d $\left.\mathrm{d}_{6}, 200 \mathrm{MHz}\right) \delta 1.23$ (s, $6 \mathrm{H}, 2 \mathrm{xCH}_{3}$ ), 4.21 (s, $2 \mathrm{H}, \mathrm{NCH}_{2}$ ), 5.17 (s, $1 \mathrm{H}, \mathrm{H} 5$ ), 6.47 (br s, $2 \mathrm{H}, \mathrm{NH}_{2}$ ), 7.30-7.50 (m, $4 \mathrm{H}$. Ar); 
${ }^{13} \mathrm{C}$ NMR (DMSO-d 6 , $\left.50 \mathrm{MHz}\right) \delta 23.8\left(2 \mathrm{xCH}_{3}\right), 40.72\left(\mathrm{NCH}_{2}\right), 63.42(\mathrm{C} 3), 85.6(\mathrm{C} 5), 128.6,126.9 .127 .7$. 130.0, 132.8, $141.7(\mathrm{Ph}), 160.3(\mathrm{C} 4)$; MS (70 eV) m/z 271, $273\left(\mathrm{M}^{+}-15,12,4\right), 221,223$ (3, 1). 207 (5). 180, $182(4,9), 125(100), 111(6), 99(5), 89$ (16), 43 (30). Anal. Calcd for $\mathrm{C}_{12} \mathrm{H}_{15} \mathrm{ClN}_{2} \mathrm{O}_{2} \mathrm{~S}: \mathrm{C} .50 .26: \mathrm{H}$. 5.27; N, 9.77; S, 11.18; Cl, 12.36. Found: C. 50.44; H, 5.38; N, 9.67; S. 11.37; Cl, 12.49 .

\section{4-Amino-2-benzyl-3,3-dimethyl-5-methyl-2,3-dihydroisothiazole 1,1-dioxide}

(14d). Compound $11 \mathrm{~b}(0.375 \mathrm{~g}, 2.13 \mathrm{mmol})$ was refluxed with benzyl bromide $(0.28 \mathrm{~mL}, 2.34$ mmol. 1.1 equiv) and $\mathrm{K}_{2} \mathrm{CO}_{3}\left(0.323 \mathrm{~g}, 4.26 \mathrm{mmol}, 2.0\right.$ equiv) in $\mathrm{CH}_{3} \mathrm{CN}(15 \mathrm{~mL})$ for $24 \mathrm{~h}$. The mixture was filtered over Celite- 545 and the solvent was evaporated. The residue was dissolved in acetonitrile $(5 \mathrm{~mL})$ to which was added $\mathrm{NaH}$ (92 mg, $2.30 \mathrm{mmol}, 1.08$ equiv, 60\% dispersion in oil). The reaction was stirred for $22 \mathrm{~h}$ at $\mathrm{rt}$. Water (20 $\mathrm{mL}$ ) was added and the mixture was extracted with dichloromethane $(3 \times 20 \mathrm{~mL})$. The organic extracts were dried $\left(\mathrm{Na}_{2} \mathrm{SO}_{4}\right)$ and evaporated; the residue was recrystallised from ethyl acetate:acetone $(10: 1)$ to yield $14 \mathrm{~d}(0.26 \mathrm{~g}$. $46 \%$ over 2 steps) as colourless needles: $\mathrm{mp} 198-199{ }^{\circ} \mathrm{C}$; IR $(\mathrm{KBr}) \cup 3440,3350,3290.3240 .3100 .2940$. 1650, 1600, 1240, $1100 \mathrm{~cm}^{-1}$; ${ }^{1} \mathrm{H}$ NMR (DMSO-d, $200 \mathrm{MHz}$ ) $\delta 1.19$ (s, $6 \mathrm{H}, 2 \mathrm{xCH}_{3}$ ). 1.70 (s. $3 \mathrm{H} . \mathrm{CH}_{3}$ C5), $4.21\left(\mathrm{NCH}_{2}\right.$ ), 5.99 (br s, $2 \mathrm{H}, \mathrm{NH}_{2}$ ), 7.20-7.50 (m, $5 \mathrm{H}, \mathrm{Ph}$ ); ${ }^{13} \mathrm{C}$ NMR (DMSO-d 6 , $50 \mathrm{MHz}$ ) $\delta 5.10$ $\left(\mathrm{CH}_{3}\right.$-C5), $29.9\left(2 \mathrm{xCH}_{3}\right), 41.3\left(\mathrm{NCH}_{2}\right), 62.1(\mathrm{C} 3), 91.7(\mathrm{C} 5), 126.9,127.9,128.0,138.7(\mathrm{Ph}), 153.5(\mathrm{C} 4)$ : MS $(70 \mathrm{eV}) \mathrm{m} / \mathrm{z} 266\left(\mathrm{M}^{+}, 3\right), 251$ (12), 201 (2), 187 (12), 148 (3), 125 (3), 91 (100), 65 (16). Anal. Calcd for $\mathrm{C}_{13} \mathrm{H}_{18} \mathrm{~N}_{2} \mathrm{O}_{2} \mathrm{~S}: \mathrm{C}, 58.62 ; \mathrm{H}, 6.81 ; \mathrm{N}, 10.52 ; \mathrm{S}, 12.04$. Found: $\mathrm{C}, 58.79 ; \mathrm{H}, 6.98 ; \mathrm{N}, 10.32: \mathrm{S} .12 .23$

4-Amino-2-benzyl-3,3-dimethyl-5-phenyl-2,3-dihydroisothiazole 1,1-dioxide (14e). Compound 11c $(0.76 \mathrm{~g}, 3.20 \mathrm{mmol})$, benzyl bromide $\left(0.45 \mathrm{~mL}, 3.84 \mathrm{mmol}, 1.2\right.$ equiv) and $\mathrm{K}_{2} \mathrm{CO}_{3}(0.88 \mathrm{~g}$. 6.40 mmol. 2 equiv) in $\mathrm{CH}_{3} \mathrm{CN}(20 \mathrm{~mL})$ were refluxed for $4 \mathrm{~h}$. The mixture was filtered and the residue wals purified by column chromatography (3:1, hexane:ethyl acetate) to yield first a mixture of benzyl bromide and the intermediate 13e, then pure 13e (404 mg, 38\%) and finally compound $35(181 \mathrm{mg}, 17 \%)$. The intermediate $13 \mathrm{e}(400 \mathrm{mg}, 1.22 \mathrm{mmol})$ was stirred with $\mathrm{DBU}\left(0.038 \mathrm{~mL}, 0.42 \mathrm{mmol}, 0.34\right.$ equiv) at $\mathrm{rt}$ for $5 \mathrm{~h}$ in $\mathrm{CH}_{3} \mathrm{CN}(5$ $\mathrm{mL})$. The solvent was evaporated and column chromatography of the residue (2:1-1:I, hexane:ethyl acetate) gave $14 \mathrm{e}$ (301 $\mathrm{mg}, 75 \%$ from 13e) as a colourless solid: $\mathrm{mp} 187-189{ }^{\circ} \mathrm{C}$ (from ethyl acetate): $\mathrm{IR}$ ( $\mathrm{KBr}$ ) v 3480, 3355, 3290, 3230, 2940, 1650, 1620, 1145, $1100 \mathrm{~cm}^{-1}$; ${ }^{1} \mathrm{H}$ NMR (DMSO- ${ }_{\mathrm{d} 6}, 300 \mathrm{MHz}$ ) $\delta 1.34$ (s. $6 \mathrm{H}$. $2 \mathrm{xCH}_{3}$ ), 4.31 (s, $2 \mathrm{H} . \mathrm{NCH}_{2}$ ), 6.51 (br s, $2 \mathrm{H}, \mathrm{NH}_{2}$ ), 7.22-7.54 (m, $10 \mathrm{H}, 2 \mathrm{xPh}$ ): ${ }^{13} \mathrm{C}$ NMR (DMSO-d, .50 $\mathrm{MHz}) \delta 24.0\left(2 \mathrm{xCH}_{3}\right), 41.4\left(\mathrm{NCH}_{2}\right), 62.0(\mathrm{C} 3), 98.0(\mathrm{C} 5), 126.7-138.6(2 \mathrm{xPh}) .154 .5(\mathrm{C} 4): \mathrm{MS}$ (70 eV) $\mathrm{m} /$ $328\left(\mathrm{M}^{+}, 12\right), 313(14), 263(2), 187(2), 117$ (7), 91 (100). Anal. Calcd for $\mathrm{C}_{18} \mathrm{H}_{20} \mathrm{~N}_{2} \mathrm{O}_{2} \mathrm{~S}: \mathrm{C}, 65.83: \mathrm{H}$. $6.14 ; \mathrm{N}, 8.53 ; \mathrm{S}, 9.76$. Found: C, 65.99; H, 6.36; N, 8.78; S. 9.62 .

\section{4-Amino-2-(m-chlorobenzyl)-3,3-dimethyl-5-phenyl-2,3-dihydroisothiazole 1,1-}

dioxide (14f). Compound $13 \mathrm{f}(0.57 \mathrm{~g}, 1.52 \mathrm{mmol})$ in acetonitrile $(15 \mathrm{~mL})$ was stirred with DBU $10.08 \mathrm{~mL}$. $0.88 \mathrm{mmol}, 0.58$ equiv) for $6.5 \mathrm{~h}$ at $\mathrm{rt}$. The solvent was evaporated and column chromatography $(1: 1$. hexane:ethyl acetate) yielded $14 \mathrm{f}(266 \mathrm{mg}, 47 \%)$ after recrystallisation from acetone as colourless crystals: mp 194-196 ${ }^{\circ} \mathrm{C}$; IR (KBr) $\cup 3470,3340,3220,2940,1650,1250,1145 \mathrm{~cm}^{-1}:{ }^{1} \mathrm{H}$ NMR (DMSO-d, $200 \mathrm{MHz}$ ) $\delta$ 1.35 (s, $\left.6 \mathrm{H}, 2 \mathrm{xCH}_{3}\right), 4.33$ (s, $2 \mathrm{H}, \mathrm{NCH}_{2}$ ), 6.53 (br s, $2 \mathrm{H}, \mathrm{NH}_{2}$ ), $7.20-7.55$ (m, $9 \mathrm{H}$, aromat.): ${ }^{13} \mathrm{C} \mathrm{NMR}$ (DMSO-d, $50 \mathrm{MHz}) \delta 23.6\left(2 \mathrm{xCH}_{3}\right), 40.5\left(\mathrm{NCH}_{2}\right), 61.7$ (C3), 97.3 (C5), 129.7-141.4 (aromat.). 154.1 (C4); MS (70 eV) m/z 362, $364(23,9), 347,349(40,15), 297(1), 283,285(5,2), 235(3), 125(100), 117$ (15), 99 (6), 89 (32). Anal. Calcd for $\mathrm{C}_{18} \mathrm{H}_{19} \mathrm{ClN}_{2} \mathrm{O}_{2} \mathrm{~S}: \mathrm{C}, 59.58 ; \mathrm{H}, 5.28 ; \mathrm{N}, 7.72 ; \mathrm{S}, 8.84: \mathrm{Cl}, 19.77$. Found: C, $59.77 ; \mathrm{H}, 5.45 ; \mathrm{N}, 7.53 ; \mathrm{S}, 8.91 ; \mathrm{Cl}, 19.64$. 


\section{Anti-HIV Activity Assays}

The human immunodeficiency virus strains used were HIV-1(III $\left.{ }_{\mathrm{B}}\right)$ and HIV-2(ROD) whose origin has been described previously. ${ }^{32}$. Anti-HIV activity and cytotoxicity measurements were carried out in parallel. They were based on the viability of MT-4 cells that had been infected with HIV and then exposed to various concentrations of the test compounds. After the MT-4 cells were allowed to proliferate for 5 days, the number of viable cells was quantified by a tetrazolium-based colorimetric 3-(4,5-dimethylthiazol-2-yl)-2.5diphenyltetrazolium bromide (MTT) procedure in 96-well microtrays. ${ }^{33}$ In all of these assays. viral input (viral multiplicity of infection, MOI) was 0.01 , or 100 times the $50 \%$ cell culture infective dose $\left(\mathrm{CCID}_{5,1}\right)$.

\section{ACKNOWLEDGEMENTS.}

J. L. M thanks Dr. M. J. Camarasa for fruitful discussions during the progress of this work. J. L. M thanks CICYT (SAF97-0048-02; SAF94-0818-02), European Union (Human Capital and Mobility Program: Contract Nr. ERBCHRXCT920027) and Janssen-Cilag (Toledo, Spain) for generous financial support. The investigations were supported in part by the Biomedical Research Programme of the European Commission and by grants from the Belgian National Fonds voor Wetenschappelijk Onderzoek, the Belgian Fonds voor Geneeskundig Wetenschappelijk Onderzoek and the Belgian Geconcerteerde Onderzoeksacties. We are grateful to Kristien Erven, Cindy Heens and Barbara Van Remoortel for excellent technical assistance.

\section{NOTES AND REFERENCES}

1. (a) De Clercq, E. Med. Res. Rev. 1996, 16, 125; (b) Dorsey, B. D.: Levi, R. B.: McDonald. S. L.: Vacca, J. P.; Guare, J. P.; Darke, P. L.; Zugay, J. A.; Emini, E. A.; Schleif, W. A.: Quintero. J. C.: Lin, J. H.; Chen, I. W.; Holloway, M. K.; Fitzgerald, P. M. D.; Axel, M. G.; Ostovic, D.: Anderson. P. S.; Huff, J. R. J. Med. Chem. 1994, 37, 3443; (c) Burke Jr., T. R.; Fesen, M. R.: Mazumder. A.; Wang, J.; Carothers, A. M.; Grunberger, D.; Driscol, J.; John, K.; Pommier, Y. J. Med. Chem. 1995. $38,4171$.

2. De Clercq, E. J. Med. Chem. 1995, 38, 2491.

3. (a) Richman, D. D.; Fischl, M. A.; Grieco, M. H.; Gottleib, M. S.; Volberding, P. A.; Laskin. O. L.: Leedom, J. M.; Groopman, J. E.; Mildvan, D.; Hirsch, M. S.; Jackson, G. G.; Durack. D. T.: NusinoffLehrman, S. N. Engl. J. Med. 1987, 317, 192; (b) Larder, B. A.; Kemp, S.D.Science 1989. 246. 1155.

4. Buckheit, R. W.; Fliakas-Boltz, V.; Decker, W. D.; Robertson, J. L.; Pyle, C. A.; White, E. L.: Bowden, B. J.; McMahon, J. B.; Boyd, M. R.; Bader, J. P.; Nickell, D. G.; Barth, H.; Antonucci. T. K. Antiviral Res. 1994, 25, 43.

5. Witvrouw, M.; Arranz, M. E.; Pannecouque, C.; De Clercq, R.; Jonkheere, H.; Schmit. J. C.: Vandamme, A. M.; Díaz, J. A.; Ingate, S. T.; Desmyter, J.; Esnouf, R.; Van Meervelt, L.; Vega, S.: Balzarini, J.; De Clercq, E. Antimicrob. Agents. Chemother. submitted for publication (1997). 
6. Pérez-Pérez, M. J.; San-Félix, A.; Balzarini, J.; De Clercq, E.; Camarasa, M. J.J. Med. Chem. 1992. 35, 2721

7. Pauwels, R.; Andries, K.; Debyser, Z.; Van Daele, P. A.; Schols, D.; Stoffels, P.; De Vreese, K.; Waestenborghs, R.: Vandamme, A. M.; Janssen, C. G. M.; Anné, J.; Cauwenbergh, G.; Desmyter. J.: Heykants, J.; Janssen, M. A. C.; De Clercq, E.; Janssen, P. A. J. Proc. Natl. Acad. Sci. USA 1993. $90,1711$.

8. Ahgren, K.; Backro, K.; Bell, F. W.; Cantrell, A. S.; Clemens, M.; Colacino, J. M.: Deeter. J. B.: Engelhardt, J. A.; Hogberg, M.; Jaskunas, S. R.; Johansson, N. G.; Jordan, C. L.: Kasher. J. S.: Kinnick, M. D.; Lind, P.; López, C.; Morin Jr., J. M.; Muesing, M. A.; Noreen, R.; Oberg. B.: Paget. C. J.; Palkowitz, J. A.; Parrish, C. A.; Pranc, P.; Ribby, M. K.; Rydegard, C.; Sahlberg.C.: Swanson. S.; Ternansky, R. J.; Unge, T.; Vasileff, R. T.; Vrang, L.; West, S. J.; Zhang, H.; Zhou. X.-X. Antimicob.Agents. Chemother. 1995, 39, 1329.

9. Baba, M.; Yuasa, S.; Niwa, T.; Yamamoto, M.; Yabuchi, S.; Takashima, H.: Ubasawa. M.: Tanaka. H.: Miyasaka, T.; Walker, R. T.; Balzarini, J.; De Clercq, E.; Shigeta, S. Biochem. Phamacol. 1993. 45. 2507.

10. Massa, S.; Mai, A.; Artico, M.; Sbardella, G.; Tramontano, E.; Loi, A. G.; Scano, P.; La Colla, P. Antiviral Chem. Chemother. 1995, 6, 361.

11. (a) Kohlstaedt, L. A.; Wang, J.; Friedman, J. M.; Rice, P. A.; Steitz, T. A.Science 1990. 256, 1783 ; (b) Ren, J.; Esnouf, R.; Garman, E.; Somers, D.; Ross, C.; Kirby, I.; Keeling, J.; Darby, G.: Jones, Y.; Stuart, D.: Stammers, D. Nat. Struct. Biol. 1995, 2, 293 (c) Esnouf, R. M.; Ren. J.: Hopkins. A L.; Ross, C. K.; Jones, E. Y.; Stammers, D. K.; Stuart, D. I. Proc. Natl. Acad. Sci . USA 1997. 94 3984.

12. Schäfer, W.; Freibe. W. G.; Leinert, H.: Mertens, A.; Poll, T.; von der Saal, W.; Zilch. H.: Nuber, B.: Ziegler, M. L. J. Med. Chem. 1993,36, 726.

13. Ingate, S. T.; Pérez-Pérez, M. J.; De Clercq, E.; Balzarini, J.; Camarasa, M. J. Antiviral Res. $1995,27$. 281 .

14. Ingate, S. T.; Camarasa, M. J.; De Clercq, E.; Balzarini, J. Antiviral Res. 1996,32, 149.

15. Balzarini, J. ; Naesens, L.; Bohman, C.; Pérez-Pérez, M. J.; San-Félix, A.: Camarasa. M. J.: De Clercq. E. Biochem. Pharmacol. 1993, 46, 69.

16. Tronchet. J. M. J.; Kovacs, I.; Barbalat-Rey, F.; Dolotshahi, N.Nucleosides and Nucleotides 1996.15. 337.

17. Pérez-Pérez, M. J.; Balzarini, J.; Hosoya, M.; De Clercq, E.; Camarasa, M. J. Bioorg. Med. Chem. Lett. 1992, 2, 647.

18. Preliminary communication: Marco, J. L.; Ingate, S.T.Tetrahedron Lett. 1997,38, 4835.

19. Calvo-Mateo, A.; Camarasa, M. J.; Díaz-Ortíz, A.; de las Heras, F. G. J. Chem. Soc., C/hem. Commun. 1988,1114 .

20. Stachel, H. D.; Drasch, G. Arch.Pharm. 1985, 318, 304.

21. Alvarez, R. Ph.D Thesis Autómoma University, Madrid, Spain, 1996, pp. 71.

22. Taylor, E. C. J. Am. Chem. Soc. 1952,74, 1648;

23. (a) Duffield, J. J.; Regan, A. C. Tetrahedron Asymmetry 1996,7, 663; (b) Effenburger, F. Angew: Chem. Int. Ed. Engl. 1993,33, 1555. 
24. North, M.Synlett., 1993, 807.

25. Allen, A. D.; Kitumura, T.; McClelland, R. A.; Strang, P. J.; Tidwell, T. T. J. Am. Chem. Soc. $1990,112,8873$.

26. Yoneda, R.; Santo, K.; Harusawa, S.; Kurihara, T.Synthesis 1986, 1054.

27. (a) Stork, G.; Ozorio, A. A.; Leong, A. Y.Tetrahedron Lett. 1978, 5175; (b) Albright, J. D.Tetrahedrom 1983,39, 3207; (c) Mai, K.; Patel, G.Synth.Commun. 1985,15, 157.

28. Gulewitsch, W.; Wasmus, T.Chem.Ber. 1905,39, 1181.

29. Moore, J. E.; Yang, Y.-L.; Griffith, R. K.; Chan, D. Ch.-K. Eur. Pat. Appl. 0176327 Al.

30. Chem-3D-Pro Version 3.2, Cambridge Soft Corporation, Cambridge, Mass 02139.

31. Jpn. Kokai Tokyo. Koho JP 03, 240, 764 [91, 240, 764]. The synthesis of compound 2a is described in detail in Chem. Abs. 116: P105644e. We have not found this compound in any other source and hence describe the synthesis here.

32. De Clercq, E; Yamamoto, N; Pauwels, R; Baba, M.; Schols, D.; Nakshima, H.; Balzarini, J.: Debyser. Z.; Murrer, B.A.; Schwartz, D.; Thornton, D.; Bridger, G.; Fricker, S.; Henson, G.: Abrams, M.: Picker, D; Proc.Natl.Acad.Sci.USA, 1992, 89, 5286.

33. Pauwels, R.; Balzarini, J.; Baba, M.; Snoeck, R.; Herdewijn, P.; Desmyter, J.; De Clercq. E. J. Virol. Methods, 1988, 20, 309.

(Received in UK 26 September 1997; revised 17 October 1997; accepted 23 October 1997) 